\title{
A mini-review of the morphological properties of biosorbents derived from plant leaves
}

\author{
Joshua O. Ighalo' ${ }^{10} \cdot$ Adewale George Adeniyi ${ }^{1}$ (I)
}

Received: 24 January 2020 / Accepted: 25 February 2020 / Published online: 28 February 2020

(c) Springer Nature Switzerland AG 2020

\begin{abstract}
A key feature of biosorption studies is the utilisation of different analytical techniques to evaluate several aspects of the process. Scanning electron microscopy (SEM) is used to study the morphology features of biosorbents. In this mini-review, research efforts by scientists in evaluating the morphological properties of plant leaves biosorbents was discussed. The way in which results have been interpreted and what inferences have been deduced was also discussed. Biosorbents obtained from plant leaves generally possess heterogeneous and irregular surface containing a variety of cavities, holes, voids, cracks, interstices and convolutions. $\mathrm{NaOH}$ pre-treatment (also known as mercerisation) helps to remove lignin and oil from the biomass as well as increasing the roughness of the base cellulose. Smoother surfaces with fewer features are observed after sorption of some chemical species (be it pollutants or a modification agent). It was observed that impregnation with nanoparticles usually leads to nanoparticle macro-clusters observable at high resolutions while any previously observed cavities, holes, ruptures and voids tends to disappear. Carbonisation and calcination gives a more porous adsorbent. Chemical modification despite reducing the total surface area of the adsorbent can actually increase the adsorption capacity due to adjustments in functional groups, effects on the solution chemistry and the improvement of the inherent affinity of the biosorbent due to the modification. SEM analysis is even more important in recent times where the functionalisation of adsorbents and biosorbents is a common practice.
\end{abstract}

Keywords Adsorption · SEM · Plant leaves · Biosorbent · Morphology analysis

\section{Introduction}

Energy and environmental sustainability is of major concern to environmental engineers in contemporary times. In light of these, researchers have over the years developed numerous techniques for the treatment of polluted effluents [1, 2]. A popular technique is adsorption by biomaterials also known as biosorption [3]. A plethora of biological materials have been studied over the years and these includes fish scales [4, 5], plant leaves [6, 7], tree barks [8], agricultural wastes [9], egg shells [10, 11], fruit pods, fruit shells [12] and a host of others. Plant leaves have had a wave of research papers (in biosorption studies) in recent times due to their low cost and availability all year round. Adeniyi and Ighalo [6] observed that nations like India, Pakistan, Malaysia, Turkey and China has a large number of plant leave biosorption studies due to their lingering issues of water pollution, urbanisation and industrialisation (leading to poor management of industrial effluents). In a bid to further assist researchers in their quest for environmental sustainability via plant leave biosorption, there is a need to delve into the analytical findings of the adsorbents themselves.

A key feature of biosorption studies is the utilisation of different analytical techniques to evaluate several aspects of the biosorbent in other to gain an

Joshua O. Ighalo, oshea.ighalo@yahoo.com; $\square$ Adewale George Adeniyi, adeniyi.ag@unilorin.edu.ng|'Department of Chemical Engineering, Faculty of Engineering and Technology, University of Ilorin, P.M.B. 1515, Ilorin, Nigeria. 
understanding of the potentials and suitability of the material to do the intended job. Branueur-Emmet-Teller (BET) analysis is used to study the particle and pore dimensional characteristics of the biosorbents. Fourier transform infra-red spectroscopy (FTIR) done to determine the functional groups and complexes present in the biosorbent that could be responsible for pollutant uptake. X-ray fluorescence (XRF) is used to analyse the major and trace elements in the biomaterials by studying the behaviour of atoms when they interact with radiation. X-ray diffractometry (XRD) to used investigate the properties of the adsorbent as it relates to the crystallinity of the material.

Microscopy is used to study the morphological features materials. We have Optical Microscopy (OM) and Electron Microscopy (SEM). OM produce coloured images but is greatly limited in terms of resolution [13]. Despite the grey-scale images of SEM, resolution 1000 times greater than that of OM can be achieved. Scanning electron microscopy (as well as the transmission electron microscopy) has been used quite a while is studying the surface morphology of adsorbent materials. Transmission Electron Microscopy (TEM) is also used to study particle morphology albeit to give more detailed images at higher resolutions and confirm the presence of specific molecules on the particle surface [14]. The use of TEM is not as common as SEM in open literature probably due to its high cost.

In a recent paper, we discussed the empirical findings of researchers in plant leaves biosorption and evaluated possible knowledge gaps and research trends [6]. In this mini-review, we put forward a discussion of research efforts by scientists in evaluating the morphological properties of plant leaves biosorbents and conclude on how these results have been interpreted and what inferences have been deduced. The possible effects of modification and pollutant loading on the biosorbents are also discussed. The pool of literature is gotten from (but not exclusive to) all studies investigating plant leaves biosorbents using SEM over the past 10 years and obtained from google scholar. Within the scope of the author's exhaustive search, there is no such literature in this regard that carefully examines the morphological properties and transformations of biosorbents from plant leaves. This leaves an important knowledge gap to be filled. A review such as this will serve as an important template to researchers in discussing the images from their SEM analyses, help them gain better understanding of the significance of what they actually see in those micrographs and assist in gaining a deeper understanding of the possible information that can be drawn from these images. 'Biosorbents' in the context of this paper refers to special type of adsorbents that have not undergone any high temperature process (e.g. carbonisation and pyrolysis) and are simply grinded from the source leaves and chemically modified (in some cases) at ambient or near-ambient conditions.

\section{Overview of scanning electron microscopy}

In this section we take a brief historical examination of SEM analysis to understand the fundamental principles behind the technology and gain a historical preview of its development. In SEM, a fine probe of energised electrons (having energies up to $40 \mathrm{keV}$ ) is projected on a specific sample and scanned along a pattern of parallel lines [15]. Various signals are generated due to the incidence of the electrons on the sample surface and these are collected to form an image [15]. These incident rays are mostly secondary electrons (the high energy electrons backscattered from the primary beam). More details of the physics of the process is given by Klein et al. [16]. SEM technology is based on two fundamental discoveries. The first is the observation that trajectories of charged particles in axially symmetric electric and magnetic fields could act as particle lenses indirectly laying the foundations of geometrical electron optics in 1926 [15]. The second was the introduction of the wave electron optics which was based on the concept of the corpuscule (leading to the assigning of a frequency and a wavelength to a charged particle) around the same time. The first commercially available SEM (then known as 'stereoscan') was developed by Cambridge instruments and made available in the open market in 1965 [17]. A more detailed discussion of the background history of SEM development is presented by McMullan [18] and Haguenau et al. [19]. Most SEM now come with dispersive and non-dispersive X-ray analysers as attachments [17]. X-ray dispersive analysis (EDX) works hand in hand with SEM to provide a qualitative and quantitative information about the composition of the material [13]. SEM though initially designed for applications in biology for the examination of inorganic materials [20] has now found applications in many other research areas (such as the one considered in the mini-review)

\section{Instrumentation of scanning electron microscopy}

A variety of scanning electron microscopes are used in studies and reported in open literature. Procedural overview of SEM analyses is explained in literature [21, 22]. However, most studies on plant leaves biosorption did not give any discussion of the procedure. In the description by Adeniyi et al. [21], a double adhesive was placed on a sample stub. The sample was the sprinkled on the stub and subsequently taken to a sputter coater with 
$5 \mathrm{~nm}$ of gold. The sample was placed on a charge reduction sample holder and introduced into the column of the SEM machine. It was firstly viewed from a Navigation Camera before being sent to SEM mode. The spectrum was recorded using transmittance method in the $4000-650 \mathrm{~cm}^{-1}$ region with numerous sample scans. The acceleration voltage of the microscope was set to $15 \mathrm{kV}$ and magnification of 500-1500 times. Different magnifications were stored in a USB stick after adjustment of brightness and contrast. Different SEM models have different image magnification and clarity that is why it is pertinent that the model be stated. It is also to ensure reproducibility of the results. Also, a few studies did not mention the model of SEM machine used in their study $[23,24]$.

\section{Evaluation of analytical findings}

\subsection{Guava (Psidium guajava)}

Abdelwahab et al. [24] studied the morphology of unmodified and modified guava leaves biosorbent. The SEM image of the unmodified biosorbent is shown in Fig. 1a while Fig. $1 \mathrm{~b}$ reveals that of the modified biosorbent. The biosorbent was modified by soaking in a $1 \mathrm{M} \mathrm{NaOH}$ solution for $24 \mathrm{~h}$. It was observed that the unmodified biosorbents possess a heterogeneous surface with deep ridged cavities. Upon chemical modification, the surface of the biosorbents became more ridged. Further explanations and elaborations were not given from their observations. Conventionally, $\mathrm{NaOH}$ treatment (also known as mercerisation) helps to remove lignin and oil from the biomass as well as increasing the roughness of the cellulose [25]. It was proposed that the adsorption mechanism was either boundary layer diffusion or intra-particle diffusion or both. The findings revealed that both biosorbents adsorbed $\mathrm{Cd}$ (II) according to second order kinetics, but clear distinctions between both types was unfortunately not made.

\subsection{Aloe Vera}

Abedi et al. [26] studied the morphological features unmodified (Fig. 2a) and magnetically modified (Fig. 2b) aloe vera ash biosorbents. The biosorbents were modified using iron oxide nanoparticles and used for the adsorption of $\mathrm{Pb}$ (II), $\mathrm{Cu}(\mathrm{II}), \mathrm{Zn}(\mathrm{II})$ and $\mathrm{Cr}(\mathrm{II})$. The unmodified biosorbents was observed to have a rough surface structure with flaky micro-particles of which the authors inferred to mean the possible presence of cavities. However, impregnation with iron oxide nanoparticles completely transformed the micro-structure of the adsorbent (see Fig. 2b). The spherical cage-like structures formed was an indication of homogeneity between biosorbent and the nanoparticles. Much
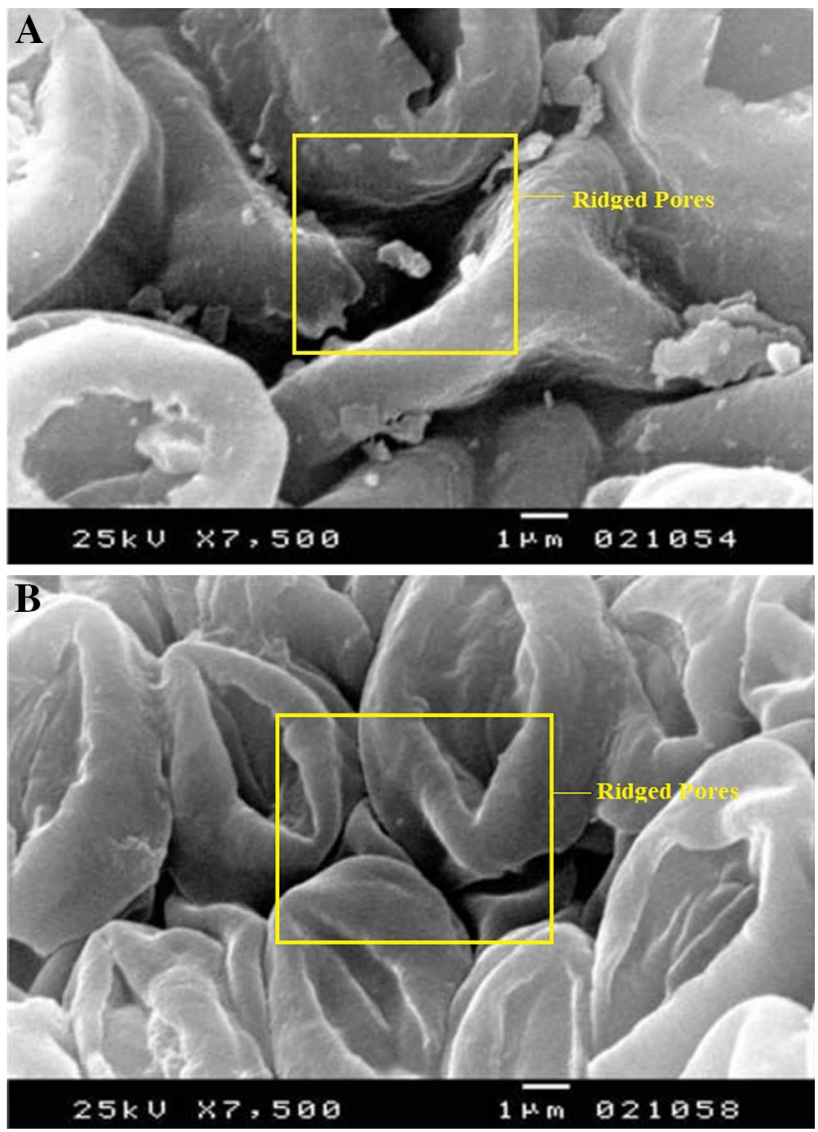

Fig. 1 a SEM image of unmodified Guava leaves biosorbent at $\times 7500$ magnification [24]. b SEM image of modified Guava leaves biosorbent at $\times 7500$ magnification [24]

of the active sites were observed to have been occupied by the nanoparticles hence the seemingly more homogeneous appearance. For the magnetically modified biosorbent after adsorption of heavy metals, the almost homogenous surface suggests that virtually all cavities on the surface have been occupied by the nanoparticles or pollutants. Overall, it was observed that the heavy metal adsorption process for was rapid and $>98 \%$ removal efficiency was achieved at optimised conditions. The morphological observations of Abedi et al. [26] is corroborated by Malik et al. [27] in their study.

\subsection{Tea}

The morphology of spent black tea leaves before and after phenol adsorption was evaluated in a study by Ali et al. [28]. The original adsorbent (Fig. 3a) had a diversified, coarse and highly porous surface composed of numerous fibrous bonds and spongy formations. After the adsorption of phenol (Fig. 3b), much of the observed cavities were no longer observed and the surface had a more homogenous appearance. This is quite similar to the 

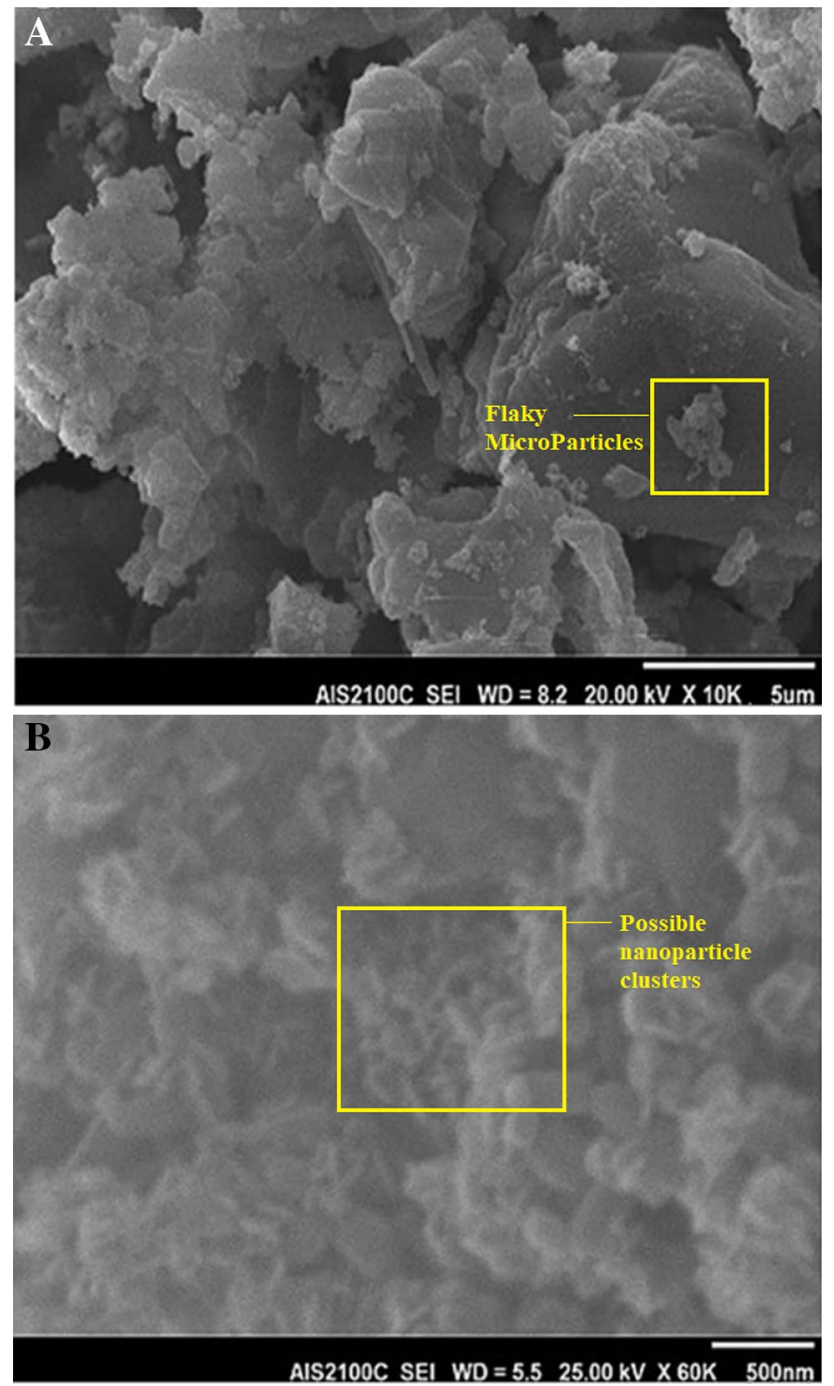

Fig. 2 a SEM image of unmodified Aloe vera leaves ash biosorbent at $\times 10,000$ magnification [26]. b SEM image of magnetically modified Aloe vera leaves ash biosorbent at $\times 60,000$ magnification [26]

observations of Abedi et al. [26] albeit for aloe vera. Bajpai and Jain [29] also examined spent tea leaves at a lower magnification of $50 \times$ and $800 \times$ (images not shown). Their study was however focused on the adsorption of crystal violet. The macro-structure of the biosorbent particles could be clearly noticed from the images and the surface heterogeneity summarily confirmed.

\subsection{Neem (Azadirachta indica)}

The SEM image of Neem leaves powder by Bharali and Bhattacharyya [23] revealed a surface with a porous look with a large number of craters (Fig. 4a). Several irregular convolutions also seem to appear on the surface. After sorption of fluoride (Fig. 4b), the porous outlook was partly destroyed as the craters were no longer noticeable. The
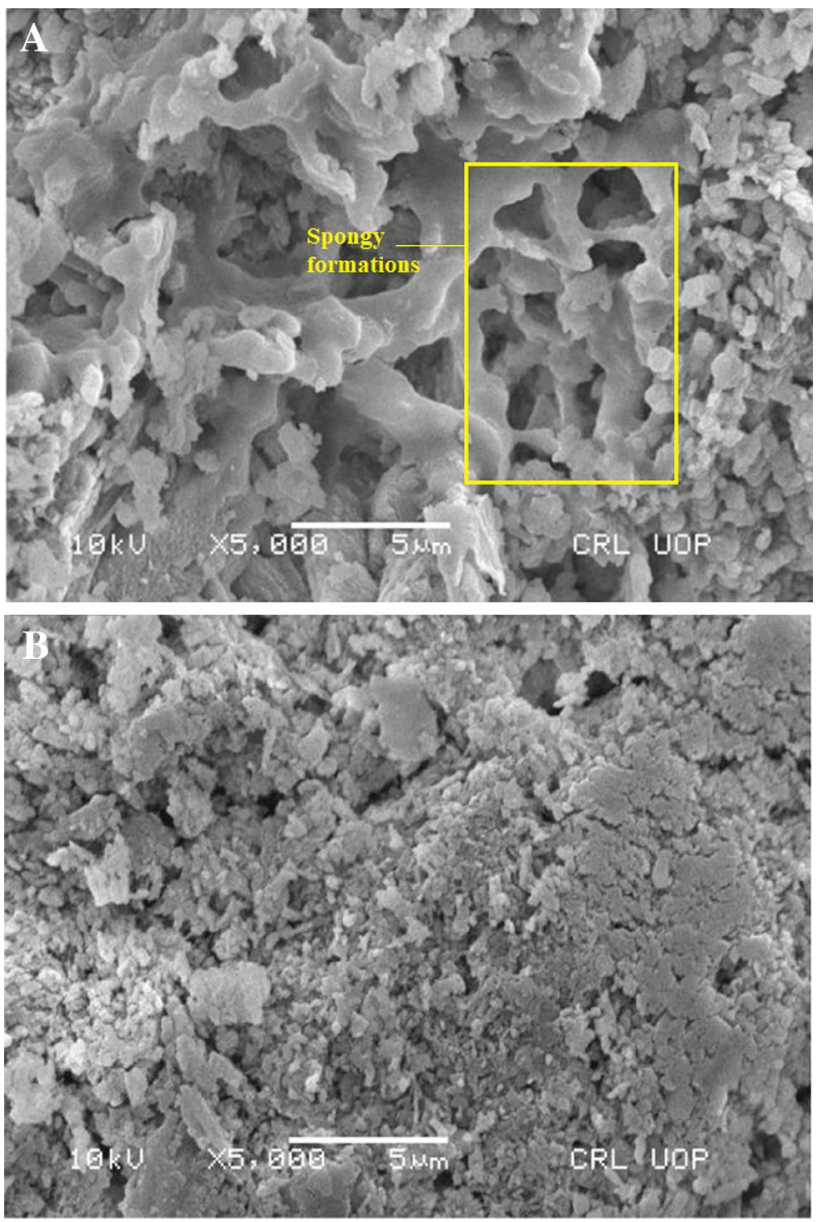

Fig. 3 a SEM image of spent black tea leaves at $\times 5000$ magnification [28]. $\mathbf{b}$ SEM image of spent black tea leaves after adsorption at $\times 5000$ magnification [28]

authors attributed this to the sorption of fluoride unto the cavities and over the cracks on the surface of the biosorbent. Neem leaves was found to be an effective adsorbent in the uptake of fluoride from aqueous solution ( $>80 \%$ removal efficiency). The morphological findings of Bharali and Bhattacharyya [23] is in consonance with the previously observed reduction in heterogeneity due to the adsorption of some chemical species. Bhattacharyya and Sharma [30] had earlier examined neem leaves powder albeit at a higher magnification of $4000 \times$ and $20,000 \times$ (images not shown) in a study focused on $\mathrm{Pb}$ (II) biosorption. Similar convolutions, irregularities and broken edges was also observed.

\subsection{Bael (Aegle marmelos)}

Chakravarty et al. [31] examined the morphology of Beal leaves powder adsorbent for loaded (Fig. 5a) and unloaded (Fig. 5b) specimens. The study evaluated the

\section{SN Applied Sciences}



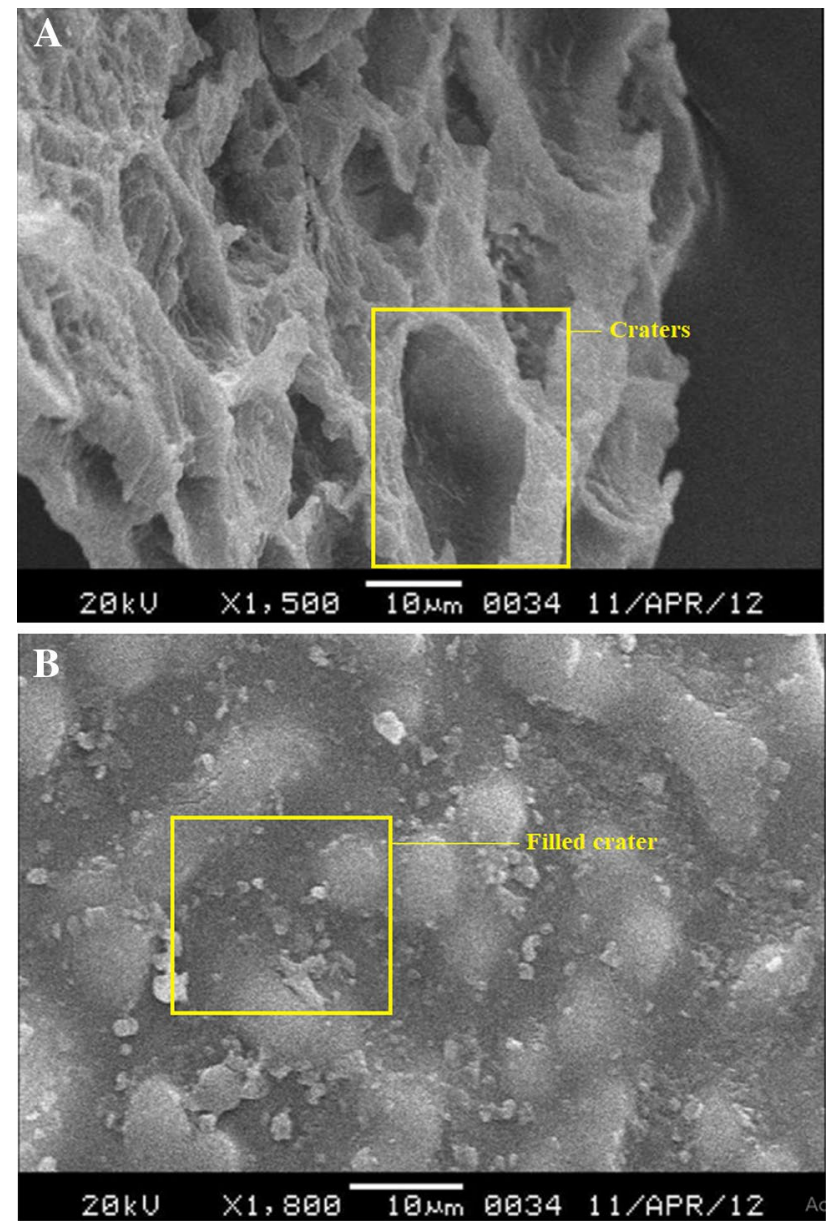

Fig. 4 a SEM image of Neem leaves powder at $\times 1500$ magnification [23]. b SEM image of Neem leaves powder after adsorption at $\times 1500$ magnification [23]

biosorption of $\mathrm{Pb}(\mathrm{II})$. The un-used/unloaded specimens showed a regular symmetry with hollow tubular structures. After biosorption of $\mathrm{Pb}(\mathrm{II})$, the tubes become noticeably swollen as the metal enters the fibers of the leaves. It was put forward by the authors that $\mathrm{Pb}(\mathrm{II})$ is adsorbed to the functional groups present inside the wall of the tubular structures of the leaves. This inference was corroborated by their FTIR analysis. The biosorption process was described as physisorption and an adsorption capacity of about $104 \mathrm{mg} / \mathrm{g}$ was calculated. At a resolution ten times that of Chakravarty et al. [31], Sahu et al. [32] observed the hollow tubular structures of bael leaves biosorbent and some cavities. The study went on to observe the smoothening out of the surface after impregnation with ferromagnetic nanoparticles.
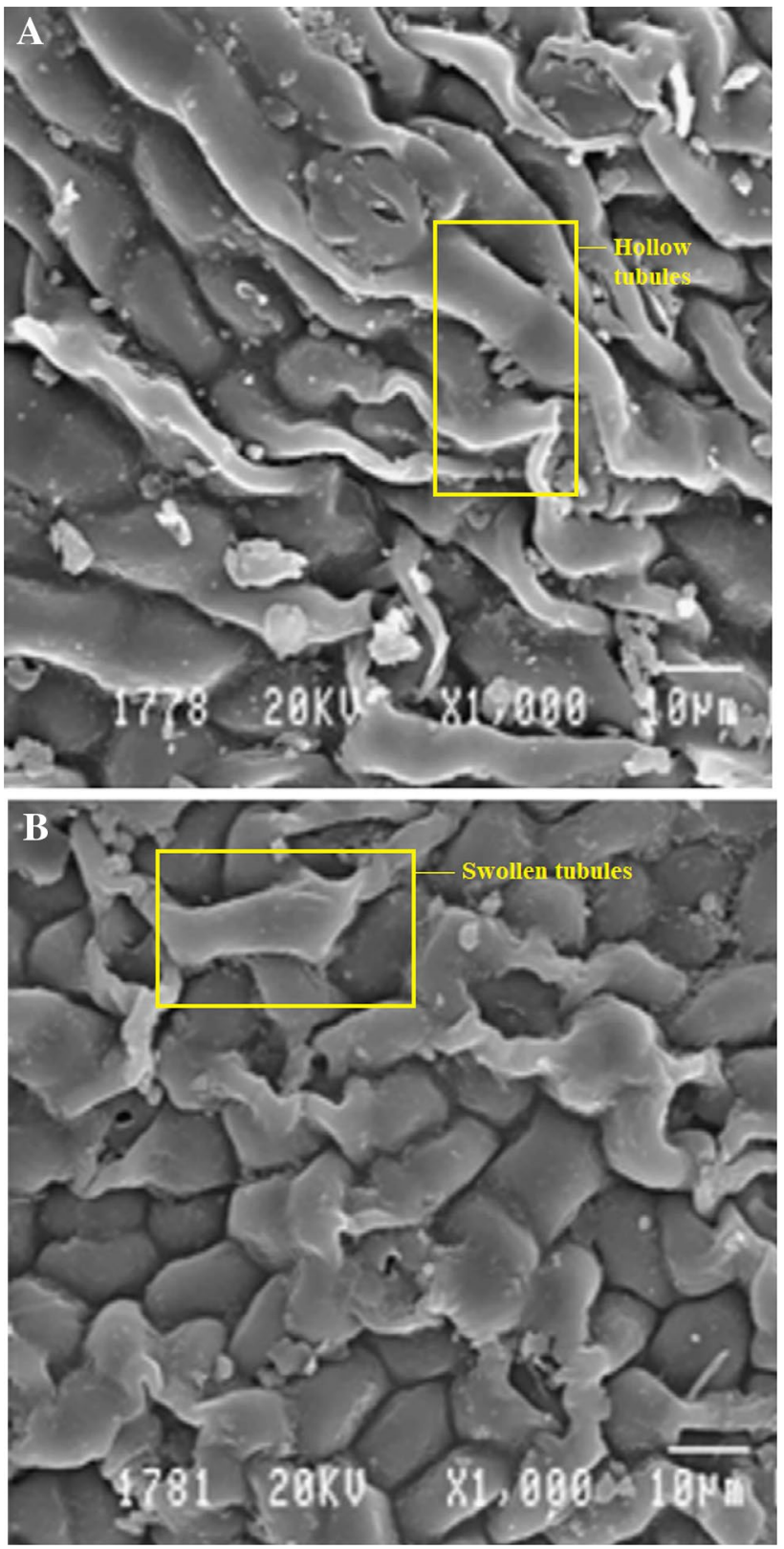

Fig. 5 a SEM image of Bael leaves powder at $\times 1000$ magnification [31]. b SEM image of Bael leaves powder after adsorption at $\times 1000$ magnification [31]

\subsection{Coconut (Cocos nucifera $L$.}

Jawad et al. [33] studied the morphology of unused (Fig. 6a) and used (Fig. 6b) adsorbent obtained from coconut leaves. The adsorbent was used for the sorption of methylene blue. From the micrographs, chemical activation with phosphoric acid was useful in developing a mesoporous structure within the carbon. The pores are formed due to the evaporation of the activating agent during high temperature carbonisation. This therefore 

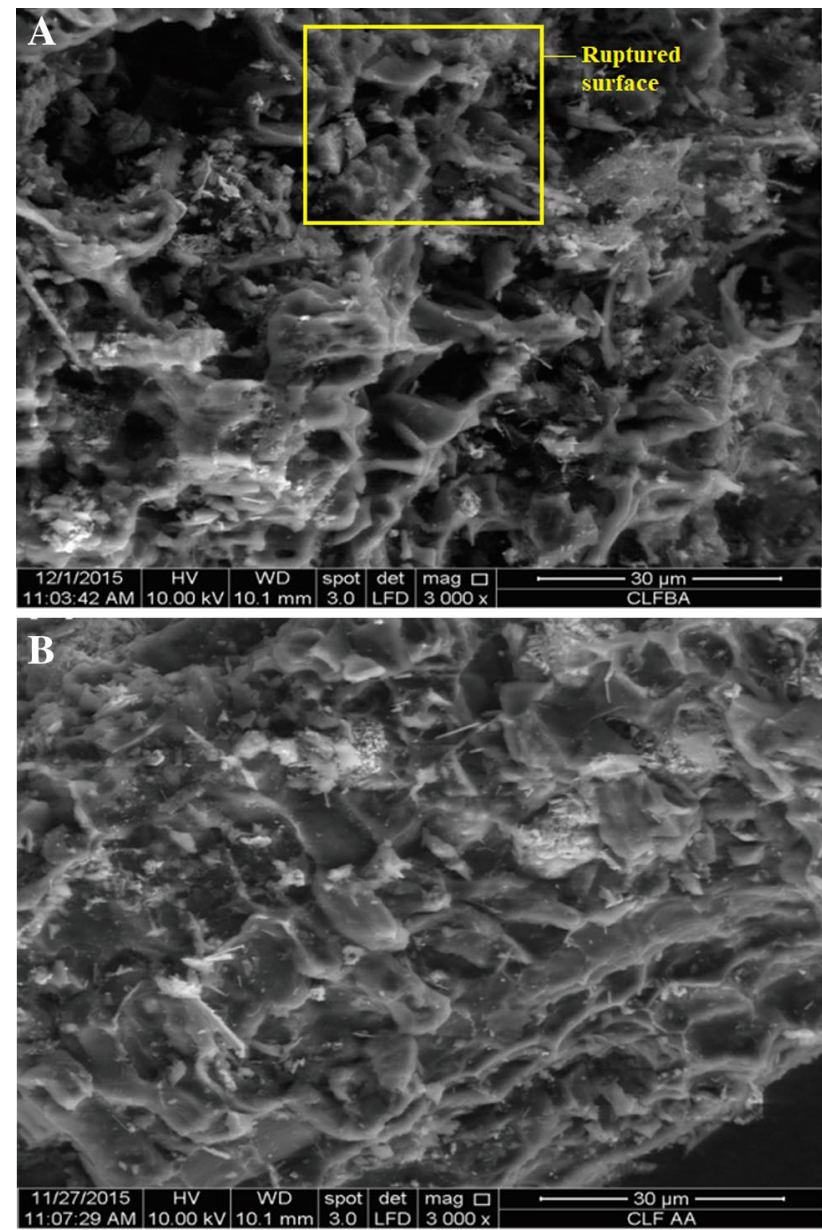

Fig. 6 a SEM image of coconut leaves activated carbon at $\times 3000$ magnification [33]. b SEM image of coconut leaves activated carbon after adsorption at $\times 3000$ magnification [33]

leaves behind a ruptured surface of the carbon with numerous cavities previously occupied by the activating chemical agent. The surface area of the activated carbon was very high at $981.79 \mathrm{~m}^{2} / \mathrm{g}$. The external surface has cracks and crevices as well as irregular and heterogeneous morphology with a well-developed porous structure in various sizes. Due to the presence of these cavities, it was proposed by the authors the adsorbent will have a better capacity for methylene blue molecules as they can diffuse into these cavities and get trapped on active sites. Figure $6 \mathrm{~b}$ reveals that the above assumption is valid. The activated carbon surface became denser and with less open cavities on the surface.

\subsection{Tephrosia purpuria}

Madala et al. [34] studied the morphology of Tephrosia purpuria leaves biosorbent. The unmodified (Fig. 7a), acid modified (Fig. 7b) and used biosorbent (Fig. 7c) were
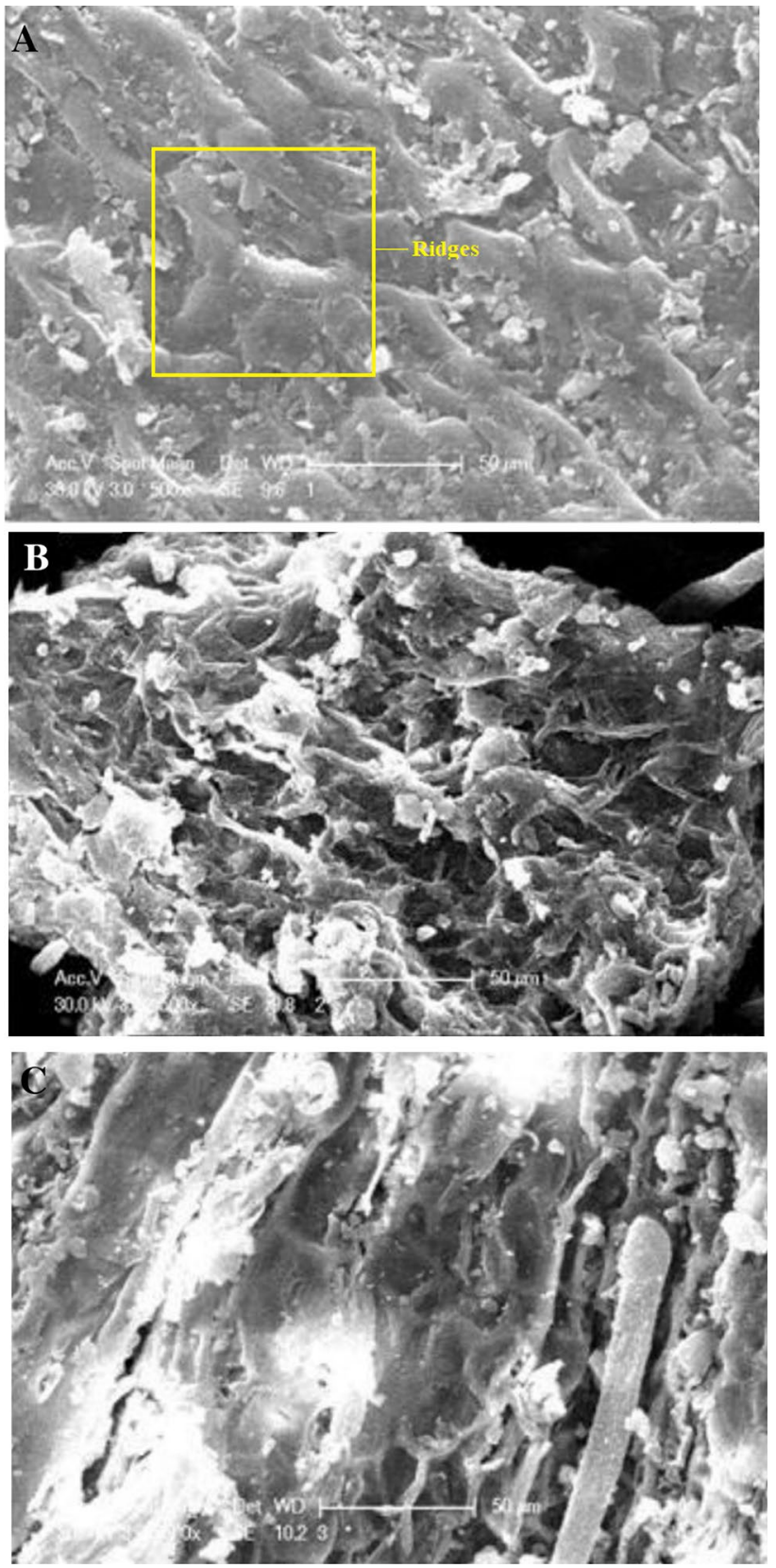

Fig. 7 a SEM image of raw Tephrosia purpuria leaves biosorbent at $\times 500$ magnification [34]. b SEM image of modified Tephrosia purpuria leaves biosorbent at $\times 500$ magnification [34]. c SEM image of modified Tephrosia purpuria leaves biosorbent after adsorption at $\times 500$ magnification [34]

examined. The unmodified biosorbent had a uniform and regular structure with observable ridges. After acid modification, the surface of the biosorbent became more porous and heterogeneous due to ruptures induced by the acid treatment. Akhabue et al. [35] observed that acid treatment of biomass leads to ruptures on the surfaces. After adsorption, there was a noticeably smoothening out of the biosorbent surface as $\mathrm{Pb}$ (II) ions are adsorbed onto 
the adsorbent. The modified biosorbent had an adsorption capacity of $100 \mathrm{mg} / \mathrm{g}$ and the process was highly feasible, spontaneous and exothermic.

\subsection{Rubber (Hevea brasiliensis)}

Fadzil et al. [36] described modified (Fig. 8b) and unmodified (Fig. 8a) rubber leaves biosorbent in their study. The biosorbent was modified with monosodium glutamate. Both the unmodified and modified biosorbents were described as jagged, irregular in shape and with nooks and crannies. Though modification did not make the surface smoother, the modified biosorbent had a less jagged look but with identifiably organised crevices running on the surface (Fig. 8b). A similar observation was made by Kamal et al. [37] for chemical treated rubber leaves, though the irregularities on the surface of the biosorbent was greater in their case. Nag et al. [38] was also able to show that rubber leaves biosorbents will reduce in surface heterogeneity after pollutant sorption. Other researchers have also examined the micrographs of rubber leaves biosorbents $[39,40]$.
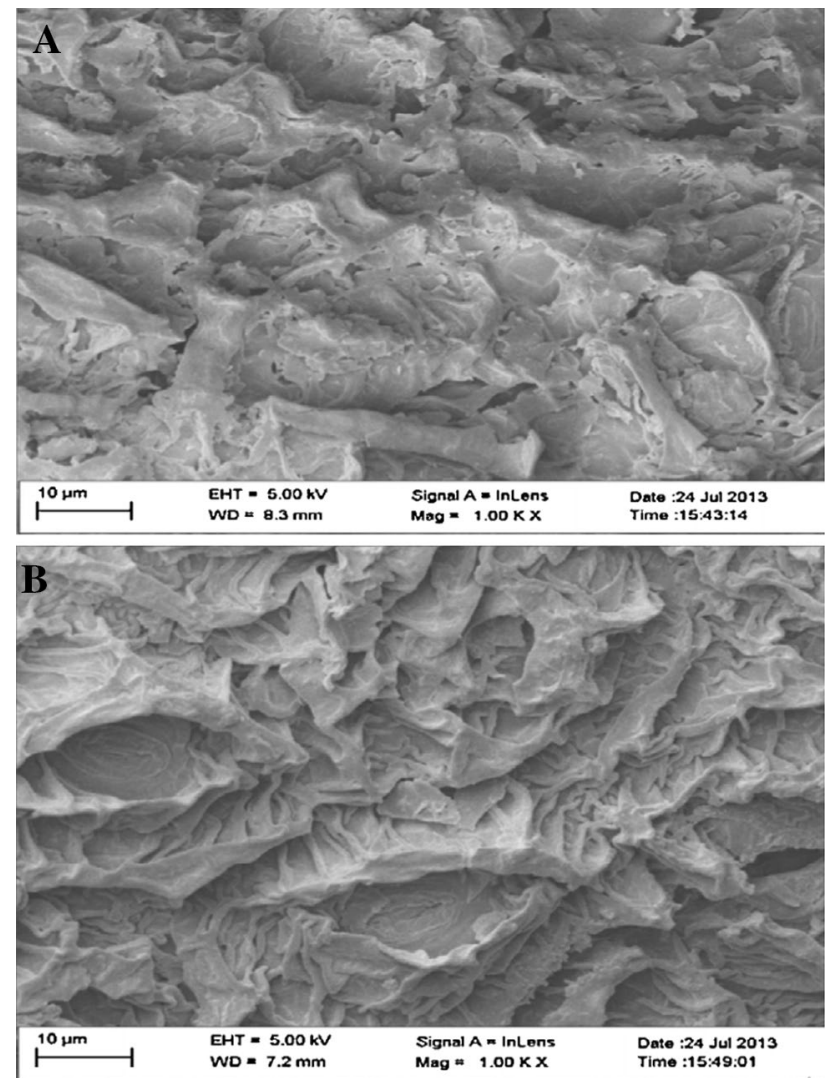

Fig. 8 a SEM image of Rubber leaves biosorbent at $\times 1000$ magnification [36]. b SEM image of modified Rubber leaves biosorbent at $\times 1000$ magnification [36]

\section{Comparison of adsorption capacities of plant leaves derived biosorbents}

In this section, a comparison is made of the adsorption capacities of raw and modified biosorbents derived from plant leaves for different pollutants. The comparison for heavy metals is shown in Table 1 and for other pollutant in Table 2. The discussion in this section was restricted to studies where direct comparison was made in this domain. It would be erroneous to make generalisations across several studies as not only chemical modification can affect the adsorption capacity. Other factors like functional groups, solution chemistry, $\mathrm{pH}$, sorbate-sorbent interphase and affinity can also affect the adsorption capacity. Only a few studies directly compared the modified and unmodified adsorbents. Dabbagh et al. [41] compared the adsorption capacities of Ficus carica for Co(II) for unmodified adsorbent and those modified with $\mathrm{HCl}$ and $\mathrm{MgCl}_{2}$. At a pH of 6 , the adsorption capacity of the $\mathrm{MgCl}_{2}$ modified adsorbent was $33.90 \mathrm{mg} / \mathrm{g}$ followed by the untreated $(14.80 \mathrm{mg} / \mathrm{g})$ and then the $\mathrm{HCl}$ modified $(9.20 \mathrm{mg} / \mathrm{g})$. The biosorbent adsorption capacity can be improved for heavy metal sorption by reducing the electronegativity of the biomass surface. However, Dabbagh et al. [41] explained that acid treatment could cause a reduction in this electronegativity due to the protonation by the acid. The $\mathrm{Mg}^{2+}$ ions however are will readily exchange with the $\mathrm{Co}$ (II) thereby making the biosorbent to serve as a kind of ion-exchange resin. The morphological changes were unreported. El-Sayed and Nada [14] observed that oil palm leaves modified by polyethylenimine has a lesser specific surface area but a higher pollutant removal efficiency for $\mathrm{Cr}(\mathrm{VI})$ and $\mathrm{Pb}(\mathrm{II})$. Despite the reduction in the surface area, the polyethylenimine helped to functionalise the biosorbent and improve its affinity for the heavy metals.

Fadzil et al. [36] compared the use of citric acid and monosodium glutamate (MSG) in the modification of rubber leaves for $\mathrm{Pb}$ (II) adsorption. They observed that MSG was the better modification agent albeit without any comparison made to the unmodified leaves. Mondal et al. [42] utilised anionic surfactant sodium dodecyl sulphate (SDS) and non-ionic surfactant triton X-100 to modify bamboo leaf powder for the adsorption of mercury. The unmodified powders had a lesser adsorption capacity for mercury $(27.11 \mathrm{mg} / \mathrm{g})$ than the SDS $(31.05 \mathrm{mg} / \mathrm{g})$ and triton modified $(27.10 \mathrm{mg} / \mathrm{g})$ biosorbents. It should be noted that washing with $\mathrm{NaOH}$ is not considered a modification technique. It is done to leach out solubles like tannin, chlorophyll and lignin from the plant materials [6]. This is a prerequisite for it to be suitable used as an adsorbent (except when extensive 
Table 1 Adsorption capacity of plant leave biosorbents for heavy metals

\begin{tabular}{|c|c|c|c|c|c|c|}
\hline Reference & Leaves & Metal & $\mathrm{pH}$ & $\begin{array}{l}\text { Adsorption capacity } \\
\text { before modification } \\
\text { (mg/g) }\end{array}$ & $\begin{array}{l}\text { Adsorption capacity } \\
\text { after modification } \\
(\mathrm{mg} / \mathrm{g})\end{array}$ & Modification agent \\
\hline \multirow[t]{4}{*}{ Abedi et al. [26] } & \multirow[t]{4}{*}{ Aloe Vera ash } & $\mathrm{Pb}^{2+}$ & 6 & - & 333.3 & $\mathrm{Fe}_{3} \mathrm{O}_{4}$ \\
\hline & & $\mathrm{Cu}^{2+}$ & 6 & - & 3445 & $\mathrm{Fe}_{3} \mathrm{O}_{4}$ \\
\hline & & $\mathrm{Zn}^{2+}$ & 6 & - & 71.40 & $\mathrm{Fe}_{3} \mathrm{O}_{4}$ \\
\hline & & $\mathrm{Cr}^{3+}$ & 6 & - & 333.3 & $\mathrm{Fe}_{3} \mathrm{O}_{4}$ \\
\hline Aditya et al. [43] & E. variegata orientalis & $\mathrm{Cr}^{6+}$ & 3 & 6.320 & - & - \\
\hline \multirow[t]{4}{*}{ Ahluwalia and Goyal [44] } & \multirow[t]{4}{*}{ Tea } & $\mathrm{Pb}^{2+}$ & 5 & 2.096 & - & - \\
\hline & & $\mathrm{Fe}^{3+}$ & 5 & 79.53 & - & - \\
\hline & & $\mathrm{Zn}^{2+}$ & 5 & 785.6 & - & - \\
\hline & & $\mathrm{Ni}^{2+}$ & 5 & 515.1 & - & - \\
\hline Al Rmalli et al. [45] & Castor & $\mathrm{Hg}^{2+}$ & 5.5 & 37.20 & - & - \\
\hline Ananthakumar et al. [46] & Neem & $\mathrm{Cr}^{6+}$ & 5 & - & 6.925 & $\mathrm{H}_{2} \mathrm{SO}_{4}$ \\
\hline Aoyama et al. [47] & Black locust & $\mathrm{Cr}^{6+}$ & 2 & - & 25.75 & $\mathrm{HNO}_{3}$ \\
\hline Aoyama [48] & London Plane & $\mathrm{Cr}^{6+}$ & 3 & - & 83.33 & $\mathrm{HNO}_{3}$ \\
\hline Babu and Gupta [49] & Neem & $\mathrm{Cr}^{6+}$ & 2 & - & 62.97 & $\mathrm{HCl}$ \\
\hline $\begin{array}{l}\text { Bhattacharyya and } \\
\text { Sharma [30] }\end{array}$ & Neem & $\mathrm{Pb}^{2+}$ & 7 & 300.1 & - & - \\
\hline Çekim et al. [50] & Tobacco & $\mathrm{Cu}^{2+}$ & 4 & - & 17.18 & $\mathrm{H}_{2} \mathrm{SO}_{4}$ \\
\hline Chakravarty et al. [31] & Bael & $\mathrm{Pb}^{2+}$ & 5.1 & 104.0 & - & - \\
\hline Chen et al. [51] & C. camphora & $\mathrm{Pb}^{2+}$ & 5 & 75.82 & - & - \\
\hline \multirow[t]{4}{*}{ Abdel-Ghani et al. [52] } & \multirow[t]{4}{*}{ T. domingensis } & $\mathrm{Al}^{3+}$ & 2.5 & 0.348 & - & - \\
\hline & & $\mathrm{Fe}^{3+}$ & 2.5 & 2.114 & - & - \\
\hline & & $\mathrm{Zn}^{2+}$ & 2.5 & 0.201 & - & - \\
\hline & & $\mathrm{Pb}^{2+}$ & 2.5 & 0.654 & - & - \\
\hline Cheraghi et al. [53] & Sesame & $\mathrm{Cd}^{2+}$ & 5.5 & 84.74 & - & - \\
\hline Choudhary et al. [54] & L. speciosa & $\mathrm{Pd}^{2+}$ & 2 & - & 56.50 & $\mathrm{H}_{2} \mathrm{SO}_{4}$ \\
\hline Dabbagh et al. [41] & F. carica & $\mathrm{Co}^{2+}$ & 6 & 33.90 & 14.80 & $\mathrm{MgCl}_{2}$ \\
\hline Edokpayi et al. [22] & D. eriocarpum & $\mathrm{Pb}^{2+}$ & 4 & 41.49 & - & - \\
\hline \multirow[t]{2}{*}{ El-Sayed and Nada [14] } & \multirow[t]{2}{*}{ Oil palm } & $\mathrm{Cr}^{6+}$ & 2 & - & 125.0 & Polyethylenimine \\
\hline & & $\mathrm{Pb}^{2+}$ & 6 & - & 142.9 & Polyethylenimine \\
\hline Eid [55] & Oil palm & $\mathrm{Hg}^{2+}$ & 5 & - & 71.40 & $\begin{array}{l}\mathrm{Fe}_{3} \mathrm{O}_{4} \text { and Polyethylen- } \\
\text { imine }\end{array}$ \\
\hline Esheewe et al. [56] & Tea & $\mathrm{Pb}^{2+}$ & 4 & 192.3 & - & - \\
\hline \multirow[t]{2}{*}{ Fadzil et al. [36] } & Rubber & $\mathrm{Pb}^{2+}$ & 5 & - & 97.19 & Citric acid \\
\hline & Rubber & $\mathrm{Pb}^{2+}$ & 5 & - & 109.9 & Monosodium glutamate \\
\hline Ghosh et al. [57] & Tea & $\mathrm{Cu}^{2+}$ & 5.5 & 7.813 & - & - \\
\hline Gutha et al. [58] & Tomato & $\mathrm{Ni}^{2+}$ & 5.5 & 58.82 & - & - \\
\hline Hanafiah et al. [59] & Rubber & $\mathrm{Cd}^{2+}$ & 5 & 3.680 & - & - \\
\hline Hanafiah et al. [60] & I. cylindrica & $\mathrm{Cu}^{2+}$ & 5 & 11.64 & - & - \\
\hline Hossain et al. [61] & Maple & $\mathrm{Pb}^{2+}$ & 6 & 125.9 & - & - \\
\hline $\begin{array}{l}\text { Hymavathi and Prabha- } \\
\text { kar [62] }\end{array}$ & Coconut & $\mathrm{Co}^{2+}$ & 5 & 3.691 & - & - \\
\hline Ince et al. [63] & Tea & $\mathrm{Cu}^{2+}$ & 5 & 3.360 & - & - \\
\hline \multirow[t]{2}{*}{ Jorgetto et al. [64] } & Brazilian orchid & $\mathrm{Cu}^{2+}$ & 5 & 15.12 & - & - \\
\hline & & $\mathrm{Cd}^{2+}$ & 5 & 12.70 & - & - \\
\hline \multirow[t]{2}{*}{ Kaliannan et al. [65] } & S. officinarum AC & $\mathrm{Pb}^{2+}$ & 7 & 148.0 & - & - \\
\hline & & $\mathrm{Zn}^{2+}$ & 7 & 137.0 & - & - \\
\hline Kamal et al. [37] & Rubber & $\mathrm{Pb}^{2+}$ & 4 & - & 95.30 & $\mathrm{KMnO}_{4}$ and $\mathrm{Na}_{2} \mathrm{CO}_{3}$ \\
\hline
\end{tabular}


Table 1 (continued)

\begin{tabular}{|c|c|c|c|c|c|c|}
\hline Reference & Leaves & Metal & $\mathrm{pH}$ & $\begin{array}{l}\text { Adsorption capacity } \\
\text { before modification } \\
(\mathrm{mg} / \mathrm{g})\end{array}$ & $\begin{array}{l}\text { Adsorption capacity } \\
\text { after modification } \\
(\mathrm{mg} / \mathrm{g})\end{array}$ & Modification agent \\
\hline \multirow[t]{3}{*}{ Kamar et al. [66] } & \multirow[t]{3}{*}{ Cabbage } & $\mathrm{Pb}^{2+}$ & 6 & 6.310 & - & - \\
\hline & & $\mathrm{Cu}^{2+}$ & 6 & 5.740 & - & - \\
\hline & & $\mathrm{Cd}^{2+}$ & 6 & 5.070 & - & - \\
\hline Kamsonlian et al. [67] & Mango & $\mathrm{As}^{3+}$ & 7 & 214.4 & - & - \\
\hline King et al. [68] & S. cumini L. & $\mathrm{Pb}^{2+}$ & 6 & 32.47 & - & - \\
\hline Kumar et al. [69] & Teak & $\mathrm{Cu}^{2+}$ & 5 & 15.43 & - & - \\
\hline Kumar et al. [70] & Teak & $\mathrm{Zn}^{2+}$ & 5 & 16.42 & - & - \\
\hline Kumar and Gayathri [71] & Bael & $\mathrm{Pb}^{2+}$ & 5 & 4.065 & - & - \\
\hline Kumar and Kirthika [72] & Bael & $\mathrm{Ni}^{2+}$ & 6.2 & 1.527 & - & - \\
\hline Kuppusamy et al. [73] & Green honey myrtle & $\mathrm{Cr}^{6+}$ & 7 & 62.50 & - & - \\
\hline Li et al. [74] & I. cylindrica & $\mathrm{Ni}^{2+}$ & 7 & - & 19.14 & $\mathrm{H}_{2} \mathrm{SO}_{4}$ \\
\hline Li et al. [74] & I. cylindrica & $\mathrm{Ni}^{2+}$ & 7 & - & 19.28 & $\mathrm{H}_{3} \mathrm{PO}_{4}$ \\
\hline Liang et al. [75] & Phoenix & $\mathrm{Pb}^{2+}$ & 5 & 71.00 & - & - \\
\hline Madala et al. [34] & T. purpuria & $\mathrm{Pb}^{2+}$ & 6 & - & 100.0 & $\mathrm{HNO}_{3}$ \\
\hline \multirow{2}{*}{$\begin{array}{l}\text { Khokhar and Siddique } \\
\text { [76] }\end{array}$} & \multirow[t]{2}{*}{ M. azedarach L. } & $\mathrm{Pb}^{2+}$ & - & 35.06 & 28.50 & $\mathrm{HCl}$ \\
\hline & & $\mathrm{Fe}^{3+}$ & - & 38.46 & 28.57 & $\mathrm{HCl}$ \\
\hline \multirow[t]{2}{*}{ Martins et al. [77] } & \multirow[t]{2}{*}{ Castor } & $\mathrm{Cd}^{2+}$ & 5 & 38.22 & - & - \\
\hline & & $\mathrm{Pb}^{2+}$ & 5 & 67.75 & - & - \\
\hline Mohammed et al. [78] & Black tea & $\mathrm{Pb}^{2+}$ & 5 & 19.70 & - & - \\
\hline Mondal [79] & Tea & $\mathrm{Pb}^{2+}$ & 5.8 & 1.351 & - & - \\
\hline Mondal et al. [42] & Bamboo & $\mathrm{Hg}^{2+}$ & 8 & 27.11 & 31.05 & Sodium dodecyl sulphate \\
\hline Mondal et al. [42] & Bamboo & $\mathrm{Hg}^{2+}$ & 8 & 27.11 & 28.10 & Triton \\
\hline Mozumder et al. [80] & Tea & $\mathrm{Cr}^{6+}$ & 2 & 73.10 & - & - \\
\hline Nag et al. [38] & Rubber & $\mathrm{Cr}^{6+}$ & 1.5 & 22.97 & - & - \\
\hline \multirow[t]{3}{*}{ Nagpal et al. [81] } & \multirow[t]{3}{*}{ Paper mulberry } & $\mathrm{Cu}^{2+}$ & 5.5 & 43.40 & - & - \\
\hline & & $\mathrm{Pb}^{2+}$ & 5.5 & 43.90 & - & - \\
\hline & & $\mathrm{Cd}^{2+}$ & 5.5 & 30.70 & - & - \\
\hline Nakkeeran et al. [82] & C. esculenta & $\mathrm{Cr}^{6+}$ & 2 & 47.62 & - & - \\
\hline Ngah and Hanafiah [39] & Rubber & $\mathrm{Cu}^{2+}$ & 4 & 8.920 & & \\
\hline Ngah and Hanafiah [40] & Rubber & $\mathrm{Cu}^{2+}$ & 4 & - & 8.710 & $\mathrm{HCHO}$ and $\mathrm{H}_{2} \mathrm{SO}_{4}$ \\
\hline \multirow[t]{2}{*}{ Pandey et al. [83] } & Kush grass & $\mathrm{Cd}^{2+}$ & 6.5 & 19.84 & - & - \\
\hline & Bamboo & $\mathrm{Cd}^{2+}$ & 6.5 & 19.71 & - & - \\
\hline Qaiser et al. [84] & F. religiosa & $\mathrm{Pb}^{2+}$ & 4 & - & 37.45 & $\mathrm{HNO}_{3}$ \\
\hline Rafatullah et al. [85] & Oil palm & $\mathrm{Cu}^{2+}$ & 6 & - & 86.95 & $\begin{array}{l}\text { Sodium dodecyl benzene } \\
\text { sulfonate }\end{array}$ \\
\hline $\begin{array}{l}\text { Rangabhashiyam et al. } \\
\text { [86] }\end{array}$ & F. auriculata & $\mathrm{Cr}^{6+}$ & 2 & 9.803 & - & - \\
\hline Rao et al. [87] & F. religiosa & $\mathrm{Cd}^{2+}$ & 5.5 & 27.14 & - & - \\
\hline Reddy et al. [88] & Moringa & $\mathrm{Pb}^{2+}$ & 5 & 209.5 & & \\
\hline \multirow[t]{3}{*}{ Reddy et al. [89] } & \multirow[t]{3}{*}{ Moringa } & $\mathrm{Cd}^{2+}$ & 5 & - & 171.4 & Citric acid \\
\hline & & $\mathrm{Cu}^{2+}$ & 5 & - & 167.9 & Citric acid \\
\hline & & $\mathrm{Ni}^{2+}$ & 5 & - & 163.9 & Citric acid \\
\hline Sahu et al. [32] & Bael & $\mathrm{As}^{5+}$ & 3 & - & 69.65 & $\mathrm{Fe}_{2} \mathrm{O}_{3}$ \\
\hline
\end{tabular}


Table 1 (continued)

\begin{tabular}{|c|c|c|c|c|c|c|}
\hline Reference & Leaves & Metal & $\mathrm{pH}$ & $\begin{array}{l}\text { Adsorption capacity } \\
\text { before modification } \\
(\mathrm{mg} / \mathrm{g})\end{array}$ & $\begin{array}{l}\text { Adsorption capacity } \\
\text { after modification } \\
(\mathrm{mg} / \mathrm{g})\end{array}$ & Modification agent \\
\hline \multirow[t]{6}{*}{ Sangi et al. [90] } & \multirow[t]{3}{*}{ U. carpinifolia } & $\mathrm{Pb}^{2+}$ & 5 & 201.0 & - & - \\
\hline & & $\mathrm{Cd}^{2+}$ & 5 & 80.00 & - & - \\
\hline & & $\mathrm{Cu}^{2+}$ & 5 & 69.50 & - & - \\
\hline & \multirow[t]{3}{*}{ F. excelsior } & $\mathrm{Pb}^{2+}$ & 5 & 172.0 & - & - \\
\hline & & $\mathrm{Cd}^{2+}$ & 5 & 67.17 & - & - \\
\hline & & $\mathrm{Cu}^{2+}$ & 5 & 33.14 & - & - \\
\hline \multirow[t]{2}{*}{ Sert et al. [91] } & \multirow[t]{2}{*}{ P. orientalis } & $\mathrm{La}^{2+}$ & 4 & 28.65 & - & - \\
\hline & & $\mathrm{Ce}^{2+}$ & 4 & 32.05 & - & - \\
\hline $\begin{array}{l}\text { Sharma and Bhattachar- } \\
\text { yya [92] }\end{array}$ & Neem & $\mathrm{Cr}^{6+}$ & 5.5 & 145.8 & - & - \\
\hline $\begin{array}{l}\text { Sharma and Bhattachar- } \\
\text { yya [93] }\end{array}$ & Neem & $\mathrm{Cd}^{2+}$ & 9.5 & 250.0 & - & - \\
\hline \multirow[t]{3}{*}{ Shi et al. [94] } & \multirow[t]{3}{*}{ Arborvitae } & $\mathrm{Pb}^{2+}$ & 5.5 & 35.84 & - & - \\
\hline & & $\mathrm{Cu}^{2+}$ & 5.5 & 7.940 & - & - \\
\hline & & $\mathrm{Co}^{2+}$ & 5.5 & 6.780 & - & - \\
\hline \multirow[t]{2}{*}{ Van Suc and Son [95] } & \multirow[t]{2}{*}{ Mistletoe } & $\mathrm{Pb}^{2+}$ & 5.5 & 68.53 & - & - \\
\hline & & $\mathrm{Cd}^{2+}$ & 5.5 & 50.07 & - & - \\
\hline Venkateswarlu et al. [96] & Neem & $\mathrm{Cr}^{6+}$ & 7 & 49.15 & - & - \\
\hline Venkateswarlu et al. [97] & E. variegata orientalis & $\mathrm{Zn}^{2+}$ & 7 & 17.24 & - & - \\
\hline \multirow{2}{*}{$\begin{array}{l}\text { Vilvanathan and Shan- } \\
\text { thakumar [98] }\end{array}$} & \multirow[t]{2}{*}{ Teak } & $\mathrm{Ni}^{2+}$ & 6 & 18.10 & - & - \\
\hline & & $\mathrm{Co}^{2+}$ & 5 & 29.50 & - & - \\
\hline Weng and Wu [99] & Pineapple & $\mathrm{Cu}^{2+}$ & 5 & 9.280 & - & - \\
\hline Yuvaraja et al. [100] & S. melongena & $\mathrm{Pb}^{2+}$ & 5 & 71.42 & - & - \\
\hline Zolgharnein et al. [101] & C. speciosa & $\mathrm{Pb}^{2+}$ & 5 & 120.2 & - & - \\
\hline
\end{tabular}

washing is done). The comparison of adsorption capacity of plant leaves for heavy metals and other pollutants are summarised in Tables 1 and 2 respectively.

\section{Appraisal of other recent literature}

In this section, we will give a cursory discussion (but without images) of other plant leaves biosorption studies that conducted SEM analysis on their biosorbent. The analysis of Cheraghi et al. [53] on sesame (Sesamum indicum) leaves revealed that the biosorbent had a rough and irregular surface. This of course would mean a large area for interaction between the pollutants ions and the adsorbent surface. After the biosorption of $\mathrm{Cd}(\mathrm{II})$, a smoothening effect was perceived as the surface became more homogenous. The interstitial spaces, cavities and channels as also observed to have been smoothened out. Cunha et al. [119] studied the biomass precursor and the prepared adsorbents from Eragrostis plana leaves. The images revealed that the surface texture of the biomass are quite different. The biomass looked like a dense and low rugosity material without cavities. The prepared biosorbent showed an irregular surface These channels present on the surface of activated carbon allow the passage of the liquid solution through the carbon surface, allowing the mass transfer of the adsorbate from the bulk solution to the surface of the activated carbon.

The analysis of Diceriocaryum eriocarpum leave biosorbent by Edokpayi et al. [22] revealed a fluffy and highly porous and rough microstructure containing some voids and cracks. The authors' concluded that the biosorbent is suitable for the adsorption of Pb(II). Gupta et al. [112] described ashoka (Saraca asoca) leaves biosorbent as rough, irregular and laden with cavities. Han et al. [113] described poplar (Populus tremula) leaves as rough, highly heterogeneous, rough and with a porous structure. The image of the biosorbent after adsorption of methylene blue was significantly different but not necessarily smoother. The authors attributed the difference to an effective adsorption of the pollutants. They furthermore modified sulphuric acid and phosphoric to get more porous products. Hossain et al. [61] described maple (Acer spp.) leaves biosorbent as possessing asymmetric cavities 
Table 2 Adsorption capacity of plant leave biosorbents for other pollutants

\begin{tabular}{|c|c|c|c|c|c|c|}
\hline Reference & Leaves & Pollutant & $\mathrm{pH}$ & $\begin{array}{l}\text { Maximum adsorption } \\
\text { capacity before modi- } \\
\text { fication }(\mathrm{mg} / \mathrm{g})\end{array}$ & $\begin{array}{l}\text { Maximum adsorption } \\
\text { capacity after modifi- } \\
\text { cation }(\mathrm{mg} / \mathrm{g})\end{array}$ & Modification agent \\
\hline Agarry et al. [102] & Tea & Naphthalene & 7 & 23.81 & - & - \\
\hline $\begin{array}{l}\text { Tanim-al-Hasan et al. } \\
\text { [103] }\end{array}$ & Black tea & Basic violet 3 & 6 & 372.2 & - & - \\
\hline Bajpai and Jain [29] & Tea & Crystal violet & 8 & 285.7 & - & - \\
\hline $\begin{array}{l}\text { Bharali and Bhattacha- } \\
\text { ryya [23] }\end{array}$ & Neem & Fluoride & 6.8 & 9.500 & - & - \\
\hline $\begin{array}{l}\text { Bhattacharyya and } \\
\text { Sarma [104] }\end{array}$ & Neem & Brilliant green & 6.5 & 253.5 & - & - \\
\hline $\begin{array}{l}\text { Bhattacharyya and } \\
\text { Sharma [105] }\end{array}$ & Neem & Congo red & 6.7 & 128.3 & - & - \\
\hline $\begin{array}{l}\text { Bhattacharyya and } \\
\text { Sharma [106] }\end{array}$ & Neem & Methylene Blue & - & 19.61 & - & - \\
\hline Chowdhury et al. [107] & Pineapple & Basic green 4 & 9 & 54.64 & - & - \\
\hline $\begin{array}{l}\text { Deniz and Saygideger } \\
\text { [108] }\end{array}$ & P. tomentosa Steud. & Acid Orange 52 & 2 & 10.50 & - & - \\
\hline Dülger et al. [109] & Sumac & Methylene blue & 7 & 151.7 & - & - \\
\hline Elmorsi [110] & Miswak & Methylene blue & 10.6 & 200.0 & - & - \\
\hline $\begin{array}{l}\text { Gaikwad and Kinldy } \\
\text { [111] }\end{array}$ & Guava & Auramine & 9 & 7.760 & - & - \\
\hline \multirow[t]{4}{*}{ Gupta et al. [112] } & \multirow[t]{4}{*}{ Saraca asoca } & Methylene blue & 6 & 90.90 & - & - \\
\hline & & Malachite green & 6 & 83.30 & - & - \\
\hline & & Rhodamine B & 6 & 66.60 & - & - \\
\hline & & Brilliant green & 6 & 125.0 & - & - \\
\hline Han et al. [113] & Poplar & Methylene Blue & 9 & 135.4 & - & - \\
\hline Khan et al. [114] & Mango & Rhodamine B & 6 & 3.310 & - & - \\
\hline Liu et al. [115] & Boston Ivy & $\mathrm{NH}_{4}^{-}$ & 5.5 & 6.590 & - & - \\
\hline \multirow[t]{3}{*}{ Malana et al. [116] } & \multirow[t]{3}{*}{ Banyan } & Malachite green & - & 17.76 & - & - \\
\hline & & Methylene blue & - & 13.51 & - & - \\
\hline & & Methyl orange & - & 2.863 & - & - \\
\hline Mandal et al. [117] & Bamboo & Methyl orange & 7 & 125.0 & 200.0 & $\begin{array}{l}\text { Sodium dodecyl } \\
\text { sulphate }\end{array}$ \\
\hline Mandal et al. [117] & Bamboo & Methyl orange & 7 & 125.0 & 143.0 & Triton \\
\hline $\begin{array}{l}\text { Peydayesh and } \\
\text { Rahbar-Kelishami } \\
\text { [118] }\end{array}$ & P. orientalis & Methylene blue & - & 114.9 & - & - \\
\hline
\end{tabular}

and they inferred that this could be the reason for the high surface area of the adsorbent. Hanafiah et al. [60] observed that biosorbents obtained from Imperata cylindrica are interestingly non-porous but with an irregular surface. After adsorption, SEM did not observe any major changes in the morphology of the surface of the biosorbents. $\mathrm{Li}$ et al. [74] also observed an irregular surface with very few cavities.

Jorgetto et al. [64] described biosorbent particles from Brazilian orchid (Bauhinia forficata) leaves as relatively homogenous in size and irregular in shape. However, the microscopic structure is considered to be very rough. The authors furthermore opined that the particles are non-porous based on their observations. The observation of cabbage (Brassica spp.) leaves biosorbent by Kamar et al. [66] revealed a highly convoluted surface with heterogeneous crevices. Liang et al. [75] observed that calcination of biosorbents obtained from phoenix tree (Firmiana simplex) leaves gave a more porous and rough adsorbent. Makeswari and Santhi [120] studied Castor (Ricinius communis) adsorbents using SEM. Their study revealed that activation with $\mathrm{ZnCl}_{2}$ helped to improve the micro-porosity of the adsorbent. This was also observed by Makeswari and Santhi [121].

Scanning electron microscopy (SEM) have been used in numerous other plant leaves biosorption studies. 
Chowdhury et al. [107] and Weng et al. [122] examined pineapple (Ananas comosus) leaves while Choudhary et al. [54] examined Pride of India (Lagerstroemia speciose) leaves. Kaliannan et al. [65] described Saccharum officinarum leaves. Kamsonlian et al. [67] and Khan et al. [114] described mango (Mangifera indica) leaves biosorbents in their respective studies. Liu et al. [115] studied the morphology of particles obtained from Boston ivy (Parthenocissus tricuspidata) leaves. Nagda and Ghole [123] studied tendu (Diospyros melanoxylon) leaves biosorbents. Nagpal et al. [81] studied paper mulberry (Broussonetia papyrifera) leaves biosorbents. Peydayesh and Rahbar-Kelishami [118] studied Oriental plain (Platanus orientalis) leaves powder. Qaiser et al. [84] studied Sacred fig (Ficus religiosa) leave powder. Rafatullah et al. [85] and Soliman et al. [124] studied oil palm leaves powder. Rangabhashiyam et al. [86] studied Roxburgh fig (Ficus auriculata) leaves powder. Reddy et al. [88] studied Moringa oleifera leaves powder. Van Suc and Son [95] studied mistletoe (Ramus loranthi) leaves powder. Vilvanathan and Shanthakumar [98] studied teak (Tectona grandis) leaves powder. Yuvaraja et al. [100] studied Eggplant (Solanum melongena) leaves powder. Most of these studies reinforced the earlier observations from the analytical findings. The forgoing conclusions helps to marry theses inferences together.

\section{Knowledge gap}

The morphological investigations of biosorbent powders from plant leaves has revealed some very interesting observations over the years. It must be said that a broad spectrum of leaves from various plant species has been examined and the scope of investigation is definitely not lacking in width (but in depth). There are still some research gaps in terms of the depth of investigation. Most studies simply utilise SEM to emphasise the heterogeneity of the adsorbent surface and stop at that. Others proceed further to examine post-adsorption or post-modification transformations. There are a dearth of studies looking at the effect of preparation and/or pretreatment on the final particle morphology. What are the results of the basic physical and chemical procedures and how do they affect morphological transformations from the raw leaves? Furthermore, in studies where desorption has been conducted, there is need to examine the biosorbent morphology after regeneration. Does it remain morphologically similar to the parent adsorbent? If there are changes, does it affect the mechanism of adsorption for subsequent runs? These are few interesting avenues that can be pursued in the domain of the morphology of biosorbents from plant leaves.

SN Applied Sciences

A SPRINGER NATURE journal

\section{Conclusion}

Biosorbents obtained from plant leaves generally possess highly heterogeneous and irregular surface containing lots of cavities, holes, ruptures, voids, cracks, crevices, nooks, crannies, interstices and convolutions. These features are the sites that help improve surface sorption. The greater the heterogeneity of the surface of the particle, the greater the surface area and the more suitable it is for sorption of pollutants. Smoother surfaces with fewer and less convolutions and other uneven features are observed after sorption of some chemical species or impregnation with a chemical modification agent. Conventionally, $\mathrm{NaOH}$ treatment (also known as mercerisation) helps to remove lignin and oil from the biomass as well as increasing the roughness of the base cellulose. Impregnation with nanoparticles usually leads to some specific morphological transformations of the adsorbent. Nanoparticle macro-clusters are usually observable at high resolutions while any previously observed cavities, holes, ruptures and voids tends to disappear. Similar observation is made for biosorbents that have been loaded with heavy metals (after the adsorption process). Carbonisation and calcination gives a more porous and rough adsorbent because volatiles within the microstructure of the particles escape due to high temperature thereby leaving behind voids which end up as pores. It was also observed that chemical modification despite reducing the total surface area of the adsorbent can actually increase the adsorption capacity due to adjustments in functional groups, effects on the solution chemistry (controlled by the $\mathrm{pH}$ ), sorbate-sorbent interphase and the improvement of the inherent affinity of the biosorbent due to the modification. SEM analysis is even more important in recent times where the functionalisation of adsorbents and biosorbents is a common practice as it can give information on the nature of changes these agents make on the surface morphology.

Data availability Data sharing not applicable to this article as no datasets were generated or analysed during the current study

\section{Compliance with ethical standards}

Conflict of interest The authors declare that there are no conflicts of interest.

Human and animal rights This article does not contain any studies involving human or animal subjects. 


\section{References}

1. Guo Y, Qi P, Liu Y (2017) A review on advanced treatment of pharmaceutical wastewater. In: IOP conference series: Earth and environmental science. IOP Publishing

2. Patwardhan A (2017) Industrial wastewater treatment. PHI Learning Pvt. Ltd, New Delhi

3. Abbas SH, Ismail IM, Mostafa TM, Sulaymon AH (2014) Biosorption of heavy metals: a review. J Chem Sci Technol 3(4):74-102

4. Ahmadifar Z, Koohi AD (2018) Characterization, preparation, and uses of nanomagnetic $\mathrm{Fe}_{3} \mathrm{O}_{4}$ impregnated onto fish scale as more efficient adsorbent for $\mathrm{Cu}^{2+}$ ion adsorption. Environ Sci Pollut Res. https://doi.org/10.1007/s11356-018-2058-3

5. Eletta OAA, Ighalo JO (2019) A review of fish scales as a source of biosorbent for the removal of pollutants from industrial effluents. J Res Inf Civ Eng 16(1):2479-2510. https://doi. org/10.13140/RG.2.2.20511.61604

6. Adeniyi AG, Ighalo JO (2019) Biosorption of pollutants by plant leaves: an empirical review. J Environ Chem Eng. https://doi. org/10.1016/j.jece.2019.103100

7. Anastopoulos I, Robalds A, Tran HN, Mitrogiannis D, Giannakoudakis DA, Hosseini-Bandegharaei A, Dotto GL (2018) Removal of heavy metals by leaves-derived biosorbents. Environ Chem Lett. https://doi.org/10.1007/s10311-018-00829-x

8. Sebastian A, Nangia A, Prasad M (2019) Cadmium and sodium adsorption properties of magnetite nanoparticles synthesized from Hevea brasiliensis Muell. Arg. bark: relevance in amelioration of metal stress in rice. J Hazard Mater 371:261-272

9. Sud D, Mahajan G, Kaur M (2008) Agricultural waste material as potential adsorbent for sequestering heavy metal ions from aqueous solutions-a review. Biores Technol 99(14):60176027. https://doi.org/10.1016/j.biortech.2007.11.064

10. Mutavdžić Pavlović D, Ćurković L, Macan J, Žižek K (2017) Eggshell as a new biosorbent for the removal of pharmaceuticals from aqueous solutions. CLEAN Soil Air Water. https://doi. org/10.1002/clen.201700082

11. Bamukyaye S, Wanasolo W (2017) Performance of egg-shell and fish-scale as adsorbent materials for chromium(VI) removal from effluents of tannery industries in Eastern Uganda. Open Access Library J. https://doi.org/10.4236/oalib.1103732

12. Osakwe CE, Sa'id S, Zubairu A (2014) Adsorption of heavy metals from wastewaters using Adonosia digitata Fruit shells and Theobroma cacao Pods as adsorbents: a comparative study. AU J Technol 18(1):11-18

13. Mohammed A, Abdullah A (2019) Scanning electron microscopy (SEM): a review. In: Proceedings of 2018 international conference on hydraulics and pneumatics-Hervex

14. El-Sayed M, Nada AA (2017) Polyethylenimine-functionalized amorphous carbon fabricated from oil palm leaves as a novel adsorbent for $\mathrm{Cr}(\mathrm{VI})$ and $\mathrm{Pb}(\mathrm{II})$ from aqueous solution. J Water Process Eng 16:296-308

15. Bogner A, Jouneau P-H, Thollet G, Basset D, Gauthier C (2007) A history of scanning electron microscopy developments: towards "wet-STEM" imaging. Micron 38(4):390-401

16. Klein T, Buhr E, Frase CG (2012) TSEM: a review of scanning electron microscopy in transmission mode and its applications. In: Hawkes N (ed) Advances in imaging and electron physics. Elsevier, Amsterdam, pp 297-356

17. Stewart A (1985) The origins and development of scanning electron microscopy. J Microsc 139(2):121-127

18. McMullan D (1995) Scanning electron microscopy 1928-1965. Scanning 17(3):175-185

19. Haguenau $F$, Hawkes $P$, Hutchison J, Satiat-Jeunemaître $B$, Simon G, Williams D (2003) Key events in the history of electron microscopy. Microsc Microanal 9(2):96-138
20. Gordon RE (2014) Electron microscopy: a brief history and review of current clinical application. In: Day CE (ed) Histopathology. Springer, Berlin, pp 119-135

21. Adeniyi AG, Ighalo JO, Onifade DV (2019) Production of biochar from elephant grass (Pernisetum purpureum) using an updraft biomass gasifier with retort heating. Biofuels. https ://doi.org/10.1080/17597269.2018.1554949

22. Edokpayi JN, Odiyo JO, Msagati TA, Popoola EO (2015) A novel approach for the removal of lead(II) ion from wastewater using mucilaginous leaves of diceriocaryum eriocarpum plant. Sustainability 7(10):14026-14041

23. Bharali RK, Bhattacharyya KG (2015) Biosorption of fluoride on Neem (Azadirachta indica) leaf powder. J Environ Chem Eng 3(2):662-669

24. Abdelwahab O, Fouad YO, Amin NK, Mandor H (2015) Kinetic and thermodynamic aspects of cadmium adsorption onto raw and activated guava (Psidium guajava) leaves. Environ Prog Sustain Energy 34(2):351-358

25. Adeniyi AG, Onifade DV, Ighalo JO, Adeoye AS (2019) A review of coir fiber reinforced polymer composites. Compos B Eng. https://doi.org/10.1016/j.compositesb.2019.107305

26. Abedi S, Zavvar Mousavi H, Asghari A (2015) Investigation of heavy metal ions adsorption by magnetically modified aloe vera leaves ash based on equilibrium, kinetic and thermodynamic studies. Desalin Water Treat 57(29):13747-13759

27. Malik R, Lata S, Singhal S (2015) Removal of heavy metal from wastewater by the use of modified aloe vera leaf powder. Int J Basic Appl Chem Sci 5(2):6-17

28. Ali A, Bilal M, Khan R, Farooq R, Siddique M (2018) Ultrasound-assisted adsorption of phenol from aqueous solution by using spent black tea leaves. Environ Sci Pollut Res 25(23):22920-22930

29. Bajpai SK, Jain A (2012) Equilibrium and thermodynamic studies for adsorption of crystal violet onto spent tea leaves (STL). Water 4:52-71

30. Bhattacharyya KG, Sharma $\mathrm{A}$ (2004) Adsorption of $\mathrm{Pb}$ (II) from aqueous solution by Azadirachta indica (Neem) leaf powder. J Hazard Mater 113(1-3):97-109

31. Chakravarty S, Mohanty A, Sudha TN, Upadhyay A, Konar J, Sircar J, Madhukar A, Gupta K (2010) Removal of Pb(II) ions from aqueous solution by adsorption using bael leaves (Aegle marmelos). J Hazard Mater 173(1-3):502-509

32. Sahu UK, Sahu S, Mahapatra SS, Patel RK (2018) Synthesis and characterization of magnetic bio-adsorbent developed from Aegle marmelos leaves for removal of $\mathrm{As}(\mathrm{V})$ from aqueous solutions. Environ Sci Pollut Res. https://doi.org/10.1007/ s11356-018-3643-1

33. Jawad AH, Rashid RA, Ismail K, Sabar S (2017) High surface area mesoporous activated carbon developed from coconut leaf by chemical activation with $\mathrm{H}$. Desalin Water Treat 74:326-335

34. Madala S, Mudumala VNR, Vudagandla S, Abburi K (2015) Modified leaf biomass for $\mathrm{Pb}$ (II) removal from aqueous solution: application of response surface methodology. Ecol Eng 83:218-226

35. Akhabue C, Otoikhian KS, Bello D, Adeniyi AG, Ighalo JO (2019) Effect of dilute acid pre-treatment on the functional complexes and surface morphology of wood sawdust for bioethanol production. In: 18th Annual international materials congress for the Materials Society of Nigeria (MSN). University of Ilorin, Nigeria

36. Fadzil F, Ibrahim S, Hanafiah MAKM (2016) Adsorption of lead(II) onto organic acid modified rubber leaf powder: batch and column studies. Process Saf Environ Prot 100:1-8

37. Kamal MHMA, Azira WMKWK, Kasmawati M, Haslizaidi Z, Saime WNW (2010) Sequestration of toxic Pb(II) ions by chemically 
treated rubber (Hevea brasiliensis) leaf powder. J Environ Sci 22(2):248-256

38. Nag S, Mondal A, Mishra U, Bar N, Das SK (2015) Removal of chromium( $\mathrm{VI})$ from aqueous solutions using rubber leaf powder: batch and column studies. Desalin Water Treat 57(36):16927-16942

39. Ngah WW, Hanafiah M (2008) Adsorption of copper on rubber (Hevea brasiliensis) leaf powder: kinetic, equilibrium and thermodynamic studies. Biochem Eng J 39(3):521-530

40. Ngah WSW, Hanafiah MAKM (2009) Surface modification of rubber (Hevea brasiliensis) leaves for the adsorption of copper ions: kinetic, thermodynamic and binding mechanisms. J Chem Technol Biotechnol 84(2):192-201

41. Dabbagh R, Ashtiani Moghaddam Z, Ghafourian H (2016) Removal of cobalt(II) ion from water by adsorption using intact and modified Ficus carica leaves as low-cost natural sorbent. Desalin Water Treat 57(42):19890-19902

42. Mondal DK, Nandi BK, Purkait M (2013) Removal of mercury(II) from aqueous solution using bamboo leaf powder: equilibrium, thermodynamic and kinetic studies. J Environ Chem Eng 1(4):891-898

43. Aditya GVV, Pujitha BP, Babu NC, Venkateswarlu P (2012) Biosorption of chromium onto Erythrina variegata orientalis leaf powder. Korean J Chem Eng 29(1):64-71

44. Ahluwalia S, Goyal D (2005) Removal of heavy metals by waste tea leaves from aqueous solution. Eng Life Sci 5(2):158-162

45. AlRmalli SW, Dahmani AA, Abuein MM, Gleza AA (2008) Biosorption of mercury from aqueous solutions by powdered leaves of castor tree (Ricinus communis L.). J Hazard Mater 152(3):955-959

46. Ananthakumar K, Christopher C, Sivaranjana P (2009) Removal of chromium by activated charcoal derived from the leaves of Azadirachta indica. Indian J Environ Prot 29(1):36-43

47. Aoyama M, Tsuda M, Seki K, Doi S, Kurimoto Y, Tamura Y (2000) Adsorption of $\mathrm{Cr}(\mathrm{VI})$ from dichromate solutions onto black locust leaves. Holzforschung 54(4):340-342

48. Aoyama $\mathrm{M}$ (2003) Removal of $\mathrm{Cr}(\mathrm{VI})$ from aqueous solution by London plane leaves. J Chem Technol Biotechnol 78(5):601-604

49. Babu B, Gupta S (2008) Adsorption of $\mathrm{Cr}(\mathrm{VI})$ using activated neem leaves: kinetic studies. Adsorption 14(1):85-92

50. Çekim M, Yildiz S, Dere T (2015) Biosorption of copper from synthetic waters by using tobacco leaf: equilibrium, inetic and thermodynamic tests. J Environ Eng Landsc Manag 23(3):172-182

51. Chen H, Zhao J, Dai G, Wu J, Yan H (2010) Adsorption characteristics of $\mathrm{Pb}$ (II) from aqueous solution onto a natural biosorbent, fallen Cinnamomum camphora leaves. Desalination 262(1-3):174-182

52. Abdel-Ghani N, Hegazy A, El-Chaghaby G (2009) Typha domingensis leaf powder for decontamination of aluminium, iron, zinc and lead: biosorption kinetics and equilibrium modeling. Int J Environ Sci Technol 6(2):243-248

53. Cheraghi E, Ameri E, Moheb A (2015) Adsorption of cadmium ions from aqueous solutions using sesame as a low-cost biosorbent: kinetics and equilibrium studies. Int J Environ Sci Technol 12(8):2579-2592

54. Choudhary BC, Paul D, Borse AU, Garole DJ (2017) Recovery of palladium from secondary waste using soluble tannins crosslinked Lagerstroemia speciosa leaves powder. J Chem Technol Biotechnol 92(7):1667-1677

55. Eid ME-S (2018) Polyethylenimine-functionalized magnetic amorphous carbon fabricated from oil palm leaves as a novel adsorbent for $\mathrm{Hg}$ (II) from aqueous solutions. Egypt J Petrol 27(4):1051-1060

56. Esheewe A, Ackacha MA, Saeed NA (2010) Utilization of consumed green tea leaves as low cost adsorbent for removal of lead ions from polluted water. J Sebha Univ Pure Appl Sci 9(2):16-23

57. Ghosh A, Das P, Sinha K (2015) Modeling of biosorption of $\mathrm{Cu}$ (II) by alkali-modified spent tea leaves using response surface methodology (RSM) and artificial neural network (ANN). Appl Water Sci 5(2):191-199

58. Gutha Y, Munagapati VS, Naushad M, Abburi K (2015) Removal of $\mathrm{Ni}$ (II) from aqueous solution by Lycopersicum esculentum (Tomato) leaf powder as a low-cost biosorbent. Desalin Water Treat 54(1):200-208

59. Hanafiah M, Shafiei S, Harun MK, Yahya M (2006) Kinetic and thermodynamic study of $\mathrm{Cd}^{2+}$ adsorption onto rubber tree (Hevea brasiliensis) leaf powder. In: Materials science forum. Trans Tech Publ

60. Hanafiah M, Zakaria H, Ngah WW (2009) Preparation, characterization, and adsorption behavior of $\mathrm{Cu}(\mathrm{II})$ ions onto alkalitreated weed (Imperata cylindrica) leaf powder. Water Air Soil Pollut 201(1-4):43-53

61. Hossain MA, Ngo HH, Guo W, Zhang J, Liang S (2014) A laboratory study using maple leaves as a biosorbent for lead removal from aqueous solutions. Water Qual Res J 49(3):195-209

62. Hymavathi D, Prabhakar G (2017) Optimization, equilibrium, and kinetic studies of adsorptive removal of cobalt (II) from aqueous solutions using Cocos nucifera L. Chem Eng Commun 204(9):1094-1104

63. Ince M, Ince O, Asam E, Önal A (2017) Using food waste biomass as effective adsorbents in water and wastewater treatment for $\mathrm{Cu}(\mathrm{II})$ removal. At Spectrosc 38(5):142-148

64. Jorgetto AdO AC, da Silva MH, Wondracek RI Silva, Velini ED, Saeki MJ, Pedrosa VA, Castro GR (2015) Multilayer adsorption of $\mathrm{Cu}(\mathrm{II})$ and $\mathrm{Cd}(\mathrm{II})$ over Brazilian Orchid Tree (Pata-de-vaca) and its adsorptive properties. Appl Surf Sci 345:81-89

65. Kaliannan D, Palaninaicker S, Palanivel V, Mahadeo MA, Ravindra BN, Jae-Jin S (2018) A novel approach to preparation of nano-adsorbent from agricultural wastes (Saccharum officinarum leaves) and its environmental application. Environ Sci Pollut Res. https://doi.org/10.1007/s11356-018-3734-z

66. Kamar FH, Nechifor AC, Nechifor G, Al-Musawi TJ, Mohammed $\mathrm{AH}$ (2017) Aqueous phase biosorption of $\mathrm{Pb}$ (II), $\mathrm{Cu}$ (II), and Cd (II) onto cabbage leaves powder. Int J Chem Reactor Eng 15(2):1-13

67. Kamsonlian S, Suresh S, Ramanaiah V, Majumder C, Chand S, Kumar A (2012) Biosorptive behaviour of mango leaf powder and rice husk for arsenic(III) from aqueous solutions. Int J Environ Sci Technol 9(3):565-578

68. King P, Rakesh N, Beenalahari S, Kumar YP, Prasad V (2007) Removal of lead from aqueous solution using Syzygium cumini L.: equilibrium and kinetic studies. J Hazard Mater 142(1-2):340-347

69. Kumar YP, King P, Prasad V (2006) Equilibrium and kinetic studies for the biosorption system of copper(II) ion from aqueous solution using Tectona grandis Lf leaves powder. J Hazard Mater 137(2):1211-1217

70. Kumar YP, King P, Prasad V (2006) Zinc biosorption on Tectona grandis Lf leaves biomass: equilibrium and kinetic studies. Chem Eng J 124(1-3):63-70

71. Kumar PS, Gayathri $\mathrm{R}$ (2009) Adsorption of $\mathrm{Pb}^{2+}$ ions from aqueous solutions onto bael tree leaf powder: isotherms, kinetics and thermodynamics study. J Eng Sci Technol 4(4):381-399

72. Kumar PS, Kirthika K (2009) Equilibrium and kinetic study of adsorption of nickel from aqueous solution onto bael tree leaf powder. J Eng Sci Technol 4(4):351-363

73. Kuppusamy S, Thavamani P, Megharaj M, Venkateswarlu K, Lee YB, Naidu R (2016) Potential of Melaleuca diosmifolia leaf as a low-cost adsorbent for hexavalent chromium removal 
from contaminated water bodies. Process Saf Environ Prot 100:173-182

74. Li Z, Teng TT, Alkarkhi AF, Rafatullah M, Low LW (2013) Chemical modification of Imperata cylindrica leaf powder for heavy metal ion adsorption. Water Air Soil Pollut 224(4):1505

75. Liang S, Ye N, Hu Y, Shi Y, Zhang W, Yu W, Wu X, Yang J (2016) Lead adsorption from aqueous solutions by a granular adsorbent prepared from phoenix tree leaves. RSC Adv 6(30):25393-25400

76. Khokhar A, Siddique Z (2015) Removal of heavy metal ions by chemically treated Melia azedarach L. leaves. J Environ Chem Eng 3(2):944-952

77. Martins AE, Pereira MS, Jorgetto AO, Martines MA, Silva RI, Saeki MJ, Castro GR (2013) The reactive surface of Castor leaf [Ricinus communis L.] powder as a green adsorbent for the removal of heavy metals from natural river water. Appl. Surf. Sci. 276:24-30

78. Mohammed AA, Abed FI, Al-Musawi TJ (2014) Biosorption of $\mathrm{Pb}$ (II) from aqueous solution by spent black tea leaves and separation by flotation. Desalin Water Treat 57(5):2028-2039

79. Mondal MK (2010) Removal of Pb(II) from aqueous solution by adsorption using activated tea waste. Korean J Chem Eng 27(1):144-151

80. Mozumder Sl, Khan MR, Islam A (2008) Kinetics and mechanism of $\mathrm{Cr}(\mathrm{VI})$ adsorption onto tea-leaves waste. Asia-Pac J Chem Eng 3(4):452-458

81. Nagpal UM, Bankar AV, Pawar NJ, Kapadnis BP, Zinjarde SS (2011) Equilibrium and kinetic studies on biosorption of heavy metals by leaf powder of paper mulberry (Broussonetia papyrifera). Water Air Soil Pollut 215(1-4):177-188

82. Nakkeeran E, Saranya N, GiriNandagopal M, Santhiagu A, Selvaraju N (2016) Hexavalent chromium removal from aqueous solutions by a novel powder prepared from Colocasia esculenta leaves. Int J Phytoremed 18(8):812-821

83. Pandey R, Prasad RL, Ansari NG, Murthy RC (2015) Utilization of $\mathrm{NaOH}$ modified Desmostachya bipinnata (Kush grass) leaves and Bambusa arundinacea (bamboo) leaves for $\mathrm{Cd}(\mathrm{II})$ removal from aqueous solution. J Environ Chem Eng 3(1):593-602

84. Qaiser S, Saleemi AR, Umar M (2009) Biosorption of lead from aqueous solution by Ficus religiosa leaves: batch and column study. J Hazard Mater 166(2-3):998-1005

85. Rafatullah M, Sulaiman O, Hashim R, Amini M (2011) Adsorption of copper(II) ions onto surfactant-modified oil palm leaf powder. J Dispers Sci Technol 32(11):1641-1648

86. Rangabhashiyam S, Nakkeeran E, Anu N, Selvaraju N (2015) Biosorption potential of a novel powder, prepared from Ficus auriculata leaves, for sequestration of hexavalent chromium from aqueous solutions. Res Chem Intermed 41(11):8405-8424

87. Rao KS, Anand S, Venkateswarlu P (2011) Adsorption of cadmium from aqueous solution by Ficus religiosa leaf powder and characterization of loaded biosorbent. CLEAN Soil Air Water 39(4):384-391

88. Reddy DHK, Harinath Y, Seshaiah K, Reddy A (2010) Biosorption of $\mathrm{Pb}$ (II) from aqueous solutions using chemically modified Moringa oleifera tree leaves. Chem Eng J 162(2):626-634

89. Reddy DHK, Seshaiah K, Reddy A, Lee S (2012) Optimization of $\mathrm{Cd}(\mathrm{II}), \mathrm{Cu}(\mathrm{II})$ and $\mathrm{Ni}(\mathrm{II})$ biosorption by chemically modified Moringa oleifera leaves powder. Carbohyd Polym 88(3):1077-1086

90. Sangi MR, Shahmoradi A, Zolgharnein J, Azimi GH, Ghorbandoost $M$ (2008) Removal and recovery of heavy metals from aqueous solution using UImus carpinifolia and Fraxinus excelsior tree leaves. J Hazard Mater 155(3):513-522

91. Sert Ş, Kütahyali C, İnan S, Talip Z, Çetinkaya B, Eral M (2008) Biosorption of lanthanum and cerium from aqueous solutions by Platanus orientalis leaf powder. Hydrometallurgy 90(1):13-18
92. Sharma A, Bhattacharyya KG (2004) Adsorption of chromium(VI) on Azadirachta indica (Neem) leaf powder. Adsorption 10:327-338

93. Sharma A, Bhattacharyya KG (2005) Azadirachta indica (Neem) leaf powder as a biosorbent for removal of $\mathrm{Cd}$ (II) from aqueous medium. J Hazard Mater 125(1-3):102-112

94. Shi J, Fang Z, Zhao Z, Sun T, Liang Z (2016) Comparative study on $\mathrm{Pb}(\mathrm{II}), \mathrm{Cu}(\mathrm{II})$, and $\mathrm{Co}(\mathrm{II})$ ions adsorption from aqueous solutions by arborvitae leaves. Desalin Water Treat 57(10):4732-4739

95. Van Suc N, Son LN (2016) Mistletoe leaves as a biosorbent for removal of $\mathrm{Pb}(\mathrm{II})$ and $\mathrm{Cd}(\mathrm{II})$ from aqueous solution. Desalin Water Treat 57(8):3606-3618

96. Venkateswarlu P, Ratnam MV, Rao DS, Rao MV (2007) Removal of chromium from an aqueous solution using Azadirachta indica (neem) leaf powder as an adsorbent. Int J Phys Sci 2(8):188-195

97. Venkateswarlu P, Durga GV, Babu NC, Rao MV (2008) Biosorption of $\mathrm{Zn}(\mathrm{II})$ from an aqueous solution by Erythrina variegata orientalis leaf powder. Int J Phys Sci 3(9):197-204

98. Vilvanathan S, Shanthakumar S (2016) Removal of Ni(II) and $\mathrm{Co}(\mathrm{II})$ ions from aqueous solution using teak (Tectona grandis) leaves powder: adsorption kinetics, equilibrium and thermodynamics study. Desalin Water Treat 57(9):3995-4007

99. Weng C-H, Wu Y-C (2012) Potential low-cost biosorbent for copper removal: pineapple leaf powder. J Environ Eng 138(3):286-292

100. Yuvaraja G, Krishnaiah N, Subbaiah MV, Krishnaiah A (2014) Biosorption of $\mathrm{Pb}$ (II) from aqueous solution by Solanum melongena leaf powder as a low-cost biosorbent prepared from agricultural waste. Colloids Surf B 114:75-81

101. Zolgharnein J, Shariatmanesh T, Asanjarani N, Zolanvari A (2015) Doehlert design as optimization approach for the removal of $\mathrm{Pb}$ (II) from aqueous solution by Catalpa speciosa tree leaves: adsorption characterization. Desalin Water Treat 53(2):430-445

102. Agarry S, Ogunleye $O$, Aworanti O (2013) Biosorption equilibrium, kinetic and thermodynamic modelling of naphthalene removal from aqueous solution onto modified spent tea leaves. Environ Technol 34(7):825-839

103. Tanim-al-Hasan M, Hossain ML, Hossain MA (2017) Mechanism of basic violet 3 adsorption on used black tea leaves from neutral solution. Int J Sci Eng Res 8(10):1047-1055

104. Bhattacharyya KG, Sarma A (2003) Adsorption characteristics of the dye, Brilliant Green, on Neem leaf powder. Dyes Pigm 57(3):211-222

105. Bhattacharyya KG, Sharma A (2004) Azadirachta indica leaf powder as an effective biosorbent for dyes: a case study with aqueous Congo Red solutions. J Environ Manag 71(3):217-229

106. Bhattacharyya KG, Sharma A (2005) Kinetics and thermodynamics of methylene blue adsorption on neem (Azadirachta indica) leaf powder. Dyes Pigm 65(1):51-59

107. Chowdhury S, Chakraborty S, Saha P (2011) Biosorption of Basic Green 4 from aqueous solution by Ananas comosus (pineapple) leaf powder. Colloids Surf B 84(2):520-527

108. Deniz F, Saygideger SD (2010) Equilibrium, kinetic and thermodynamic studies of Acid Orange 52 dye biosorption by Paulownia tomentosa Steud leaf powder as a low-cost natural biosorbent. Bioresour Technol 101(14):5137-5143

109. Dülger Ö, Turak F, Turhan K, Özgür M (2013) Sumac leaves as a novel low-cost adsorbent for removal of basic dye from aqueous solution. ISRN Anal Chem 2013:1-9

110. Elmorsi TM (2011) Equilibrium isotherms and kinetic studies of removal of methylene blue dye by adsorption onto miswak leaves as a natural adsorbent. J Environ Prot 2:817-827 
111. Gaikwad RW, Kinldy SAM (2009) Studies on auramine dye adsorption on psidium guava leaves. Korean J Chem Eng 26(1):102-107

112. Gupta N, Kushwaha AK, Chattopadhyaya M (2012) Adsorption studies of cationic dyes onto Ashoka (Saraca asoca) leaf powder. J Taiwan Inst Chem Eng 43(4):604-613

113. Han X, Niu X, Ma X (2012) Adsorption characteristics of methylene blue on poplar leaf in batch mode: equilibrium, kinetics and thermodynamics. Korean J Chem Eng 29(4):494-502

114. Khan TA, Sharma S, Imran A (2011) Adsorption of rhodamine B dye from aqueous solution onto acid activated mango (Magnifera indica) leaf powder: equilibrium, kinetic and thermodynamic studies. J Toxicol Environ Health Sci 3(10):286-297

115. Liu H, Dong Y, Wang H, Liu Y (2010) Adsorption behavior of ammonium by a bioadsorbent-Boston ivy leaf powder. J Environ Sci 22(10):1513-1518

116. Malana MA, Amanat T, Qureshi RB, Ahmad HB (2012) Biosorptive removal of malachite green, methylene blue and methyl orange dyes from aqueous solutions by Ficus bengalensis (Banyan) tree leaves. Asian J Chem 24(7):3070-3074

117. Mandal D, Goswami A, Purkait M (2014) Treatment of colored effluent using surfactant modified bamboo leaves powder. Sep Sci Technol 49(2):221-231

118. Peydayesh M, Rahbar-Kelishami A (2015) Adsorption of methylene blue onto Platanus orientalis leaf powder: kinetic, equilibrium and thermodynamic studies. J Ind Eng Chem 21:1014-1019

119. Cunha MR, Lima EC, Cimirro NF, Thue PS, Dias SL, Gelesky MA, Dotto GL, dos Reis GS, Pavan FA (2018) Conversion of
Eragrostis plana Nees leaves to activated carbon by microwave-assisted pyrolysis for the removal of organic emerging contaminants from aqueous solutions. Environ Sci Pollut Res 25(23):23315-23327

120. Makeswari M, Santhi T (2013) Use of Ricinus communis leaves as a low-cost adsorbent for removal of $\mathrm{Cu}(\mathrm{II})$ ions from aqueous solution. Res Chem Intermed 40(3):1157-1177

121. Makeswari $\mathrm{M}$, Santhi $\mathrm{T}$ (2014) Adsorption of $\mathrm{Cr}(\mathrm{Vl})$ from aqueous solutions by using activated carbons prepared from Ricinus communis leaves: binary and ternary systems. Arab J Chem. https://doi.org/10.1016/j.arabjc.2013.10.005

122. Weng C-H, Lin Y-T, Tzeng T-W (2009) Removal of methylene blue from aqueous solution by adsorption onto pineapple leaf powder. J Hazard Mater 170(1):417-424

123. Nagda GK, Ghole VS (2011) Removal of Janus Green dye from aqueous solution by phosphoric acid carbonized agro-industrial waste. Sci Asia 37:38-42

124. Soliman AM, Elwy HM, Thiemann T, Majedi Y, Labata FT, AlRawashdeh NA (2016) Removal of $\mathrm{Pb}$ (II) ions from aqueous solutions by sulphuric acid-treated palm tree leaves. J Taiwan Inst Chem Eng 58:264-273

Publisher's Note Springer Nature remains neutral with regard to jurisdictional claims in published maps and institutional affiliations. 